\title{
Improving Access to Banking: Evidence from Kenya
}

\author{
FRANKLIN ALLEN, ELENA CARLETTI, ROBERT CULL, JUN “QJ” QIAN, \\ LEMMA SENBET, AND PATRICIO VALENZUELA*
}

This version: July 10, 2012

\begin{abstract}
Using household surveys and bank penetration data at the district-level in 2006 and 2009, we explore the impact of Equity Bank-a leading private commercial bank focusing on microfinance on the access to banking in Kenya. Equity Bank pursues distinct branching and business strategies that target underserved areas and less privileged households, unlike other commercial banks in Kenya. Equity Bank presence has a positive and significant impact on households' use of bank accounts and bank credit, especially for Kenyans with low income, no salaried job and less education, and those that do not own their own home. The findings are robust to using the district-level proportion of people speaking a minority language as an instrument for Equity Bank presence. We conclude that Equity Bank's business modelproviding financial services to population segments typically ignored by traditional commercial banks and generating sustainable profits in the process-can be a solution to the financial access problem that has hindered the development of inclusive financial sectors in many African countries.
\end{abstract}

JEL CODES: G2; O1; R2.

KEY WORDS: Equity Bank, bank penetration, bank account, minority language, microfinance.

\footnotetext{
* Allen is from the University of Pennsylvania, Carletti is from the European University Institute, Cull is from the World Bank, Qian is from Boston College, Senbet is from University of Maryland, and Valenzuela is from the European University Institute. We thank Financial Sector Deepening Trust Kenya (FSD Kenya), and in particular David Ferrand, for providing the household surveys. We have benefited from helpful comments from Samuel Makome, Randall Morck, Jonathan Robinson, Moses Sichei, John Staley and seminar/session participants at Wesleyan University and the NBER African Successes 2011 conference in Zanzibar. We are grateful to the Gates Foundation, NBER, and the authors' respective institutions for financial support. We are responsible for all the remaining errors.
} 


\section{Introduction}

Despite extensive economic and financial sector reforms over the last few decades, many SubSaharan African countries still face a severe financial development gap relative to not only the advanced economies but other peer developing economies. A key obstacle to financial development is access of the disadvantaged to finance, which would promote economic growth at the broadest scales. While the success of microfinance institutions (MFIs), such as Grameen Bank, has captured the attention of many economists and policy makers, some MFIs are now beset by non-repayment problems and high cost of financing. Meanwhile, most established commercial banks view the sectors targeted by MFIs as 'unbankable.' In fact, we are only beginning to understand the specific policies and institutions that best promote financial inclusion in environments endowed with asymmetric information, weak institutions and the absence of basic infrastructures necessary for banking (e.g., access to roads). Recent studies (e.g., Chaia et al., 2011; Honohan, 2008) show that in the early 2000s, roughly 2.5 billion adults, or half of the world's adult population, lacked any bank account; in Sub-Saharan Africa, the setting for our study, over eighty percent of the adult population lacked an account during that same period.

In this paper, we examine bank branch penetration and financial access in Kenya, a country which has made significant strides in financial inclusion and development in recent years. Kenya also

provides an interesting 'laboratory' for financial access, given the emergence of Equity Bank, a pioneering institution that devised a banking service strategy targeting low income clients and traditionally under-served territories. Listed on the Nairobi Stock Exchange, it has no government ownership share and has played a key role in integrating microfinance with formal finance while being profitable in the process.

A major challenge for empirical research on financial access is the paucity of micro-level data and the nonrandom nature of bank expansion (Burgess and Pande, 2005). In this regard, we merge a new dataset on bank branch penetration of all the large banks across all parts of Kenya with nationally representative household surveys of financial usage conducted by Financial Sector Deepening Trust Kenya (FSD Kenya) in 2006 and 2009.

The time dimension of our data allows us to exploit within-district variation in the access to banking services and a shift in the branching policy of Equity Bank. Specifically, we show that between 2006 
and 2009 Equity Bank's branching policy moved more toward minority language speaking districts than did those of other banks. We exploit this fact and use Instrumental Variables (IV) regressions to identify the impact of Equity Bank's branch penetration on households' access to banking services. We find that the presence of Equity Bank branches has a positive and significant impact on households' use of bank accounts and bank credit. The effect is particularly strong for Kenyans with low income, no salaried job and less education, and those that do not own their own home. Our results contribute to the growing literature on financial access and inclusion by providing large scale, micro-level evidence showing that Equity Bank's business model-providing financial services to the population segments ignored by traditional commercial banks and generating sustainable profits in the process - can be a viable solution to the financial access problem that has hindered the development of the financial sector in many developing countries.

From the standpoint of overall banking system in Kenya, we differentiate banks by their ownership characteristics (e.g. private domestic banks, foreign banks and government owned and/or influenced banks). All types of banks experienced substantial expansion between 2006 and 2009, with Equity Bank leading the way. Moreover, banks established new branches not only in urban districts but also in rural and arid and semi-arid districts. Given the expansion of banks over the period, it is not surprising to see that the fraction of households having a bank account increased from 14 percent in 2006 to 23 percent in 2009 based on the household surveys, and the proportion of households having a loan from a bank increased from 3 percent to 4 percent.

We examine two related questions. Do different types of banks pursue different branching strategies? And if so, do these different expansion strategies lead to different effects on households' access to banking services? In our first main set of results, we find Equity Bank pursues different branching strategies from other banks. While all banks (including Equity Bank) open a greater number of branches in urban, highly populated and English speaking districts, Equity Bank was more likely to expand to underdeveloped districts than other types of banks between 2006 and 2009 - less densely populated areas and areas where the dominant language was not English or Swahili. This is particularly important and encouraging for financial access development as population density has been identified as a major obstacle for financial sector development in Africa (Allen, Carletti, Cull, Qian, Senbet, and Valenzuela, 2012; ACCQSV), in that the most underdeveloped countries are 'trapped' in low density areas with poor road coverage. 
Second, we find that the presence of Equity Bank branches has a strong positive impact on the residents' likelihood of having access to both bank accounts and credit. For example, our regressions imply that the penetration of Equity Bank into a new district increases the probability of having a bank account between 4 and 9 percentage points. Since the proportion of households that had a bank account rose from 14 percent in 2006 to 23 percent in 2009, the impact of Equity Bank on financial access appears to be economically meaningful. As noted, the positive effect of Equity Bank on financial access is particularly strong for individuals from households with low income and less education, without their own permanent house, and lacking any member with a salaried job. These findings support the argument that the business model of Equity Bank, which targets underprivileged segments of the population that can bring in sustainable profits, has paid off in terms of greater financial inclusion.

We also find that the presence of domestic private banks (including Equity), government banks and foreign banks is positively related to use of bank accounts at the district level. Interestingly, the positive impact of the foreign banks is the smallest among the three groups. A potential explanation for these differences is that foreign banks traditionally have targeted the high-income segment of the population. These strategies are reflected in the differential requirements for opening a bank account. For instance, Equity Bank only requires an ID and a photo (which can be taken in the branch itself) to open a bank account. By contrast, foreign banks, such as Barclays, require a minimum balance of 20,000 Ksh. (about US\$222), a prohibitive amount for the lowest-income segment of the population.

We undertake a number of steps to ensure that our main results are not driven by alternative factors and potential endogeneity biases. We include individual and household characteristics to control for potential changes in (survey) sample composition between 2006 and 2009, and district fixed effects to control for time-invariant district characteristics. We also include the number of bank branches, which can be viewed as a parsimonious control for time-varying district characteristics such as economic development and bank competition. The most important, potential endogeneity bias stems from the fact that banks' branch penetration is not a random event. In this regard, we use the district-level proportion of people speaking a minority language (not English or Swahili) as an instrument for Equity Bank presence. Our results on the determinants of branching show that entering districts and regions with minority languages is a strategy that distinguishes Equity Bank 
from other banks. On the other hand, the fraction of people from a district speaking a particular language should not be directly linked to whether a particular individual or household (who may speak the same or different language) has access to a bank account. Indeed, our tests confirm the validity of this instrument, and our IV regressions (Probit and GMM) confirm the positive and significant impact of Equity Bank presence on households' access to financial services.

This paper extends the emerging literature on financial access and inclusion in developing economies as well as contemporaneous studies that focus on Kenya. Several studies have recently attempted to identify policies, services, and innovations that have a causal impact on financial inclusion through experiments based on randomized controlled trials (RCTs) conducted in developing countries. For example, combining survey and experimental evidence for rural Kenya, Dupas et al. (2012) explore the supply and demand factors behind the levels of financial inclusion. While RCTs represent an important breakthrough in the study of financial inclusion (and other topics in development economics), they may carry some limitations: sample sizes are small, contexts differ, and small variations in experimental design can affect results (Ravallion, 2009).

Thus, assessing the external validity of results generated in a specific experimental setting is a thorny issue in developing policy advice. Moreover, important developments in financial inclusion, such as the one studied in this paper, are taking place without the aid of experiments and are not amenable to study via randomization. We, therefore, view our nationally-representative evidence on branch penetration and financial access as complementary to the experimental evidence from Dupas et al. (2012), which focuses on a small set of rural communities. ${ }^{1}$

Our study is closest to Bruhn and Love (2009) who show that the entry of Mexico's Banco Azteca, which opened branches in the stores of Grupo Elecktra, a large retailer of consumer goods, in 2002, was associated with an increase in the start-up of small, informal businesses and a seven percent increase in income levels. The Kenyan episode that we investigate lacks the quasi-experimental characteristics of the Azteca study, because the increase in bank branch penetration was not random. However, the sheer magnitude of the increase in financial sector participation makes this an episode

\footnotetext{
${ }^{1}$ Our paper also expands international evidence on the determinants of access to financial services in less developed economies. Using survey data for 29,000 households from 29 transition economies, Beck and Brown (2011) investigate how the access to financial services is related to household characteristics, bank ownership structure and the development of the financial infrastructure. Beck et al. (2010) and Beck et al. (2011) also use the same surveys that we do to describe aspects of financial inclusion in Kenya.
} 
worthy of study, and our Instrumental Varaibles (IV) approach mitigates the potential endogeneity problems emerging from nonrandom branch expansions.

In addition to the emergence of Equity Bank, the Kenyan financial landscape has witnessed another innovation over the last decade that has gained global attention: the introduction of M-PESA, which operates through mobile telephones and greatly facilitates money transfer and remittance by the poor. With the same household surveys that we use, Mbiti and Weil (2011) show that M-Pesa has also contributed to financial inclusion. They find that M-PESA is primarily used for transferring money from individual to individual rather than as a vehicle for saving, and that its use increases the probability of being banked. M-PESA can, therefore, be seen as being complementary to the fuller set of financial services offered by large financial institutions, especially Equity Bank.

The remainder of the paper is organized as follows. Section II provides a motivation for the study in the context of financial development and access in Africa and Kenya. Section III describes the data and the methodologies. Section IV presents the empirical results stemming from base-line specifications and Instrumental Variable analysis, a set of robustness checks and a discussion of those results. Finally, Section V concludes.

\section{Motivation}

Many Sub-Saharan African countries face a severe financial development gap relative to not only the advanced economies but other peer developing economies. Based on the pre-crisis 2007 indicators, the liquid liabilities of financial sectors averaged about 30\% of GDP for Sub-Saharan Africa; in contrast, none of the other developing regions averaged less than 40\% (ACCQSV, 2012). The average level of credit extended to the private sector was $16.6 \%$ of GDP for the region, whereas for the other developing regions, that financial development indicator ranged from $32.5 \%$ to $43.9 \%$.

The low levels of financial development raise a natural question as to whether Africa faces a development model that is different from the rest of the world. ACCQSV (2012) build a (predicted) financial development benchmark line for each African country that is based on the experience of low income and middle income countries outside Africa. A stark financial development gap emerges when comparing the benchmark line with the actual level of financial indicators, in that most African countries have much lower levels of financial development than would be predicted based 
on their fundamentals.

African countries cannot ignore the serious financial development issues, since there is now ample empirical evidence for a positive linkage between financial development and economic development (Burgess and Pande, 2005; Levine, 2005; Rajan and Zingales, 1998). This issue is particularly important in the face of widespread poverty in Africa, since the positive relationship between financial development and economic development is suggestive of a positive linkage between finance and poverty alleviation (e.g., Beck, Demirguc-Kunt and Levine, 2007; Clarke, Xu and Zou, 2006). Studies based on macro financial development data cannot fully capture the forces at the micro level that directly affect access of the disadvantaged to finance, and local developments that inhibit or encourage financial inclusion. We need to understand the specific institutions and policies that best promote financial inclusion.

In this regard, micro-level results based on RCTs have been mixed so far, in particular with regard to access to credit. For example, Banerjee et al. (2010), who exploit the randomized expansion of a microfinance institution in urban India, find a modest increase in borrowing in neighborhoods where a branch was introduced. In the Philippines, Karlan and Zimmerman (2010, 2011) find that randomized access to credit (to somewhat richer people and at substantially higher interest rates than in the Indian experiment) had no effect on business investment.

Evidence involving savings products seems more promising. For example, Dupas and Robinson (2009) find that in Kenya low-cost, but interest-free savings accounts had large positive effects on the savings and investment of female shopkeepers. Access to a similarly structured savings device that was randomly offered to farmers in Malawi led to improved saving across seasons, greater investment, higher profit, and increased household consumption (Brune et al. 2011). These results also conform well with the fine-grained evidence from the 'financial diaries' of households in Bangladesh, India, and South Africa that shows that even very poor families can and do save, often outside of the formal financial sector presumably due to a lack of appropriate product offerings (Collins et al., 2009).

We focus on bank branch penetration and financial access in Kenya for several reasons. First, based on the cross-country analysis in ACCQSV (2012), Kenya's level of financial development is not too far off from the predicted level based on data from peer low income countries outside Africa. 
Although informal savings mechanisms, such as rotating savings and credit groups (so-called ROSCAs) and savings in livestock are still prevalent, even rural poor respondents mention 'a commercial bank' as their preferred saving mechanism if they had access to all the alternatives (Dupas et al., 2012). Moreover, as emphasized by the same authors, the fact that only a small proportion of the population uses bank accounts suggests an important latent demand for savings services. With robust economic growth it is not surprising to witness a strong bank branch expansion in recent years. ${ }^{2}$

Second, banking expansion in Kenya has coincided with the rise of Equity Bank, a pioneering forprofit bank that devised a banking service strategy targeting low income clients and traditionally under-served territories. As shown in Figure 1, it has experienced an explosive growth of its assets and a significant expansion of its banking services, and became the fifth largest bank in Kenya in terms of the share of gross assets and deposits of the whole system. Moreover, its stock is listed on the Nairobi Stock Exchange.

The number of deposit and loan accounts of Equity Bank represents around $50 \%$ and $30 \%$ of the total number of deposit and loan accounts in Kenya, respectively. Its model is also expanding to other African countries, with Equity ending the year 2010 with 5.4 million customers in Kenya, 474,000 in Uganda and 28,000 in South Sudan. The results of greater effectiveness for savings products based on RCTs discussed above in improving the lives of the poor motivates our focus on the uptake of bank accounts in our analysis. Specifically, we benchmark the effects of Equity's presence relative to the rest of the banking system in a manner similar to that used in other studies (e.g., Berger et al., 2005).

Third, we overcome the challenge of obtaining micro-level data in financial access research by merging a new dataset on bank branch expansions with national household surveys of financial usage for Kenya. These surveys are conducted in 2006 and 2009. In the next section we introduce our data sets and describe our empirical strategies.

\footnotetext{
${ }^{2}$ Because institutional and macroeconomic context tends to be more homogeneous within a single country, we avoid obstacles confronted in cross-country studies of financial development and inclusion regarding omitted (or poorly measured) variables. In addition, as emphasized by Beck et al. (2007), country-level measures of financial outreach assume a uniform distribution of bank outlets within a country's area and across its population, ignoring that bank branches are concentrated in urban areas and that bank expansions tend to target specific segments of the population.
} 


\section{Data and Methodologies}

Our dataset on bank presence is based on branch-level information that we aggregate to construct a district-level panel on the number of branches by bank. This data was constructed from multiple sources, including phone calls, official websites, banks' annual reports and government publications. The panel data set covers 45 commercial banks that operated in 65 Kenyan districts in the period between 2006 and 2009. ${ }^{3}$ This new dataset allows us to explore the relationship between bank expansion and access to banking services over time and to exploit within-district variation in bank presence. In addition, this dataset set allows us to characterize the expansion of the whole banking system as well as the expansion of specific banks (e.g., Equity Bank) and ownership characteristics of banks (e.g., private domestic banks, foreign banks and government banks).

\section{III.1 Stylized Facts}

As shown in Table 1, the Kenyan banking system expanded greatly in terms of the number of branches in recent years. Between 2006 and 2009, the total number of bank branches in Kenya increased from almost 600 to almost 1,000 (a 68 percent increase). The expansion involved all ownership categories of banks, namely domestic private banks, foreign banks and government banks. However, the expansion was particularly driven by domestic private banks, among which Equity Bank played an important role. The number of Equity Bank's branches increased from 44 to over 110 in the period 2006-2009, representing an expansion of 155 percent. No other bank experienced such growth in the same period. The number of bank branches of Barclays and Kenya Commercial Bank (i.e., the banks with the largest branch networks after Equity Bank) grew only 92 percent and 44 percent respectively. As Table 2 shows, the strong branch expansion in Kenya occurred not only in urban districts but also in rural, arid and semi-arid districts.

Our data on bank branches across districts is augmented by the FinAccess' households surveys. The 2006 surveys consist of 4,420 completed interviews, while the 2009 surveys consist of 6,598 completed interviews. The sample was constructed using a stratified three-stage design. In the first stage, the number of households to be allocated to each district was assigned. In the second stage, clusters were randomly selected from the district with each cluster comprising an equal sample of 10

${ }^{3}$ Although Kenya is currently divided into 46 districts, we take advantage of a more disaggregated country division as of the 1999 census. In that census, Kenya comprised eight provinces (Central Coast, Eastern, Nairobi, North Eastern, Nyanza, Rift Valley, and Western) that were subdivided into 69 districts; the survey data cover 65 of those districts. 
households. Finally, in the third stage, individuals within the household were randomly selected based on a listing of all household members aged 16 years and above, using the Kish Grid-diagram. ${ }^{4}$

We use the FinAccess survey in our analysis for a number of reasons. First, it captures important dimensions of financial inclusion as it was specifically designed to measure access to financial services in Kenya. Second, it also provides information on individual and household characteristics, such as education level, gender, asset ownership, income source, age group, language, location and household size. Third, it is a nationally representative household survey that covers the universe of districts in Kenya, alleviating potential sample selection bias problems. Fourth, its implementation over different years allows us to explore the within-district time variation in financial inclusion.

Based on the surveys, we construct two measures of access to banking services. The first measure is a dummy variable indicating whether an individual has a bank account. The second measure is a dummy variable indicating whether an individual has a loan from a bank. Table 3 shows that the proportion of individuals having a bank account in Kenya increased considerably in the sample period, going from 14 percent in 2006 to 23 percent in 2009. The proportion of individuals having a loan from a bank showed a more modest increase from 3 percent to 4 percent. While 95 percent of the individuals that had a loan from a bank also had a bank account, the remaining 5 percent of them did not. Finally, Table 3 also reports descriptive statistics for the other individual and household-level variables that we employ from the FinAccess survey, and these will be used as controls in our tests below.

\section{III.2 Methodologies}

We examine two related questions. Does Equity Bank pursue different branching strategies from other commercial banks? And if so, do these different expansion strategies lead to different outcomes on households' access to banking services? In order to examine the first question, we relate the number of branches by districts to a number of district-level characteristics. Our baseline specification takes the form:

$$
\text { Branches }_{d t}=\alpha+\mu_{t}+\beta X_{d}+\varepsilon_{d t}
$$

\footnotetext{
${ }_{4}^{4}$ The Kish Grid-diagram is a method that uses a pre-assigned table of random numbers for selecting individuals within a
} household to be interviewed. 
where Branches is the number of bank branches over the total number of banks in each group (based on ownership types) in district $d$ at time $t, \mu_{\mathrm{t}}$ is a dummy variable for 2009 , and $X_{d}$ is a set of control variables at the district level for 2006. These variables indicate whether the district is a rural or arid and semi-arid district, the population density of the district and the proportion of the population speaking a minority language or Swahili. We estimate this model by ordinary least square (OLS), and cluster standard errors by district for two samples: one excluding Equity Bank and one including only Equity Bank. Furthermore, to explore if the branch expansion of Equity Bank between 2006 and 2009 targeted more underdeveloped districts, we also augment our baseline specification with interaction terms between the $X_{d}$ variables and the 2009 indicator.

In order to study the second question, we estimate a Probit model of usage of banking services in which our dependent variable, Bank $k_{i d t}$, is a dummy indicating whether individual $i$ has a bank account in district $d$ at the time $t$. Our main independent variables are, Equity $d$, a dummy variable indicating whether Equity Bank operates in district $d$ at time $t$ and Branches ${ }_{d \rightarrow}$ the total number of bank branches of other banks operating in district $d$ at time $t$. The total number of bank branches can be viewed as a parsimonious control for time-varying district characteristics such as economic development and bank competition. ${ }^{5}$ The inclusion of this variable is fundamental to our identification strategy (see below), given the nonrandom nature of bank expansion in which banks favored opening branches in more developed districts. In addition, we include district fixed effects to control for time-invariant district heterogeneity. Thus, our baseline specification takes the form

$$
\operatorname{Pr}\left(\text { Bank }_{i d t}=1\right)=F\left(\alpha+\mu_{d}+\beta \text { Equity }_{d t}+\gamma \text { Branches }_{d t}+\phi z_{\text {idt }}\right),
$$

where $\operatorname{Pr}$ denotes probability, $F$ is the standard normal cumulative distribution function, $\mu_{d}$ is a set of district dummies, and $\mathfrak{z}_{\text {ddt }}$ is a vector of control variables at the individual and household level. The control variables indicate household size, education, gender, wealth (measured by an asset score), house ownership, type of job, age and language. ${ }^{6}$ The parameters $\alpha, \beta, \gamma$ and $\phi$ are estimated by maximum likelihood, with error terms clustered at the district-year level to account for possible correlation in errors across households within districts for each specific year.

\footnotetext{
${ }^{5}$ Note that our results are very similar whether or not we include Equity's branches in the calculation of the total number of branches.

${ }^{6}$ The asset score is higher if the individual owns a greater number of physical assets such as a mobile phone, television, or microwave. There are 20 asset categories and the ownership of each of them increases the asset score by one.
} 
However, Eq. (2) may produce biased estimates of the impact of bank penetration on financial access due to potential endogeneity concerns. The source of endogeneity is that bank branch expansion is not a random event. More specifically, in the absence of a policy shift in Equity Bank's branch penetration, we would expect relatively greater branch penetration in more developed districts or in districts with more growth opportunities, as more growth and growth opportunities generate more demand for financial services. There can be greater demand for financial services even without organic growth in a region: for example, households in the region would like to use bank branches to receive remittances from their relatives working outside Kenya. To summarize, if districts with more demand (or future demand) for financial services are more likely to provide access to finance, then $\beta$ would be an overestimate of the true impact of Equity Bank branch expansion. That is, Equity's presence could be more a feature of a relatively developed banking district than a cause of greater uptake of accounts. On the other hand, if Equity Bank succeeded in its policy of opening more branches in less developed districts or districts with less (perceived) growth opportunities than other branches, then the logic above suggests that $\beta$ would underestimate the true impact of Equity Bank branch expansion.

In order to alleviate the above endogeneity problems, we rerun our baseline regressions on the probability of having a bank account using an Instrumental Variables (IV) approach. Our goal is to identify the increase in bank accounts that occurred because of Equity Bank's shift in strategy. Specifically, we use the district-level proportion of people speaking a minority language (not English or Swahili) and its interaction with a 2009 dummy variable as instruments for Equity Bank branch expansion. These instruments are based on the fact that Equity Bank implemented a strategy of serving more vulnerable sectors of the population and underdeveloped areas from 2006 to 2009.

We argue that the district-level proportions of people speaking a minority language constitute valid instruments for Equity branch expansion if these variables only affect the probability of having a bank account through bank expansion. It is reasonable to argue that the fraction of people from a district speaking a particular language should not be directly linked to whether a particular individual or household has access to a bank account, which is our outcome variable. However, it is important to note that this assumption does not imply that the language that an individual speaks is not an important determinant of having a bank account. In fact, we control in all our specifications for individual languages. With the instruments, we then estimate Eq. (2) with both an IV (linear) GMM 
model and an IV Probit model.

Next, we augment our baseline specification with interaction terms between Equity $y_{d t}$ and a set of characteristics at the individual level (i.e., wealth, house ownership, education and type of job) to examine potential heterogeneities in the impact of Equity Bank presence on access to financial services. These heterogeneities allow us to assess whether Equity Bank has effectively increased access to financial services by the poor and low income people and hence fostered financial inclusion of the disadvantaged.

We also examine the impact of Equity Bank presence on financial inclusion by estimating an Ordered Probit model of the usage of banking services. In this model, our dependent variable takes the value 0 when the individual has neither a bank account nor a loan from a bank, the value 1 when the individual has a bank account, and the value 2 when the individual has a loan from a bank. ${ }^{7}$ Similar to our Probit model, our main dependent variables are Equity ${ }_{d t}$ and Branches.

Finally, as an additional robustness check, we apply a Difference-in-Differences (DD) estimation strategy to recover the treatment effect stemming from the possible shift of the Equity Bank branching policy that produced a sharp change in its penetration (see Table 1). Our exercise compares the difference in the probability of having a bank account before and after the penetration of Equity Bank for districts affected by this branch expansion with the same difference for unaffected districts. In order to conduct our DD estimations, we restrict our sample to districts without any Equity Bank branch in 2006 and include time-fixed effects. Districts without any Equity Bank branch in 2006 and 2009 represent the control group and districts without an Equity Bank branch in 2006 but with at least one branch of Equity Bank in 2009 represent the treatment group. Using this subsample of districts, our specification takes the following form

$$
\operatorname{Pr}\left(\text { Bank }_{\text {idt }}=1\right)=F\left(\alpha+\mu_{d}+\mu_{t}+\beta \text { Equity }_{d t}+\gamma \text { Branches }_{d t}+\phi z_{i d t}\right),
$$

where $\operatorname{Pr}$ denotes probability, $F$ is the standard normal cumulative distribution function, $\mu_{d}$ is a set of district dummies, $\mu_{t}$ is a set of time dummies and $\tau_{\text {idt }}$ is a vector of control variables at the individualand household-level. This specification is the most basic DD setup (with two periods and two groups), which is valid under the assumption that changes in the probability of having a bank

\footnotetext{
${ }^{7}$ Note that 95.2 percent of the individuals who have a loan from a bank also have a bank account.
} 
account over time would have been the same in individuals in both treatment and control districts in the absence of Equity Bank penetration.

\section{Empirical Results}

The primary goal is to establish evidence that the supply-side factors as represented by the expansion of bank branches, and in particular of Equity Bank, has increased access to financial services. To do this, we first examine the branching strategies followed by Equity Bank and other commercial banks in Kenya, and the results are reported in Table 4. Then, we evaluate the impact of Equity Bank presence and bank branch expansion on the use of bank accounts, and report the results in Tables 5 and 6 . Tables 7-10 report additional results and robustness checks.

\section{IV.1 Banks’ Expansion Strategies}

Different types of banks are likely to follow different expansion strategies. While foreign banks may cherry-pick a set of elite customers and prefer urban and developed areas, domestic banks may exploit their superior knowledge of culture, social norms, and local communities and have a comparative advantage in rural and underdeveloped areas. For example, as part of its expansion strategy, Equity Bank emphasized that local languages be spoken in its branches, which is important considering that 30-40 percent of the people in central Kenya cannot speak Swahili and only speak a minority language. In addition, government-owned banks may pursue non-profit goals in their branching and expansions.

As a first exploration of this issue, Figure 2 presents the number of bank branches in 2006 and 2009 for three bank groups: foreign (private) banks, government-owned and government-influenced banks, and domestic private banks. ${ }^{8}$ The figure also splits the districts along different dimensions in terms of urbanization and demographics. The figure illustrates three stylized facts. First, between 2006 and 2009 all bank groups undertook substantial branch expansions. Second, all bank groups showed a higher penetration in urban, English speaking, and highly populated and educated districts. Third, domestic private banks had greater presence, in terms of branch numbers, in underdeveloped districts, while foreign banks had the least presence in those districts. These patterns suggest that

${ }^{8}$ Government-owned banks are those in which the government owns a majority of shares. In (the two) governmentinfluenced banks the government maintains a large, but non-controlling ownership share. Throughout most of the paper, we refer to both groups collectively as "government banks." 
domestic private banks, whose expansion has been led by Equity Bank (see Table 1), played a vital role in fostering banking services in underdeveloped districts.

The foregoing stylized facts motivate our formal estimation and analysis of the determinants of bank penetration in Kenya. Table 4 reports OLS estimates on the determinants of bank penetration by district (Eq. 1), comparing Equity Bank with all others in the banking system. Our dependent variable is the number of branches by district. For banks other than Equity bank, we divided the number of branches in a district by the number of banks, to put them on a comparable basis with Equity Bank.. Our independent variables indicate the degree of urbanization, the population density of the district and the proportion of non-English speaking Kenyans. In addition, we include a dummy variable for 2009 in order to explore the extent of branch expansion during the period 20062009.

The results suggest some similarities, as well as some disparities, between Equity Bank and the others in terms of their branching strategies. On the one hand, all types of banks including Equity have greater branch penetration in urban and English speaking districts (Models 1 and 2). On the other hand, Equity Bank differs on at least two dimensions. First, the coefficients associated with rural and arid and semi-arid districts are either statistically insignificant or marginally significant at standard confidence levels for Equity Bank, while they are negative and highly significant for the other banks. Second, the expansion of Equity Bank, as indicated by the positive coefficient on the 2009 dummy variable, is highly significant. That coefficient is also significant for the rest of the banking system, but its size is only one-tenth that of the coefficient for Equity. Overall, the results in Models 1 and 2 suggest that Equity Bank has experienced a significant branch expansion relative to other banks between 2006 and 2009, particularly in underdeveloped non-urban districts.

Table 4 also indicates that the sensitivity of branch penetration to population density is lower for Equity Bank than for others. In fact, the coefficient for population density is negative and significant for Equity Bank in Model 2, indicating a preference for less densely populated districts (other factors held constant). This is particularly interesting in view of the African financial development gap observed at a macro level, in that most African countries tend to have lower levels of financial development than would be predicted based on their fundamentals (ACCQSV, 2012). One of the major findings is that population density appears to be more important for banking sector development as measured by liquid liabilities and private credit (relative to GDP) in Africa than in 
other developing countries. More specifically, while population density affects financial development in all developing countries, the relationship is much steeper for Africa. It is challenging to resolve the African financial development gap, but the evidence on Equity Bank is encouraging, since it points to the potential for financial institutions with novel strategies to foster financial inclusion and help promote convergence of the African financial development model with the rest of the developing world.

As noted from Figure 2, all types of banks increased branch penetration in urban, English-speaking areas. The distinctions between Equity's branching strategy and that of other banks are better seen, therefore, by focusing on rural, semi-arid and arid districts as we observe in Models 3-10. Equity Bank does have a stronger tendency than the other banks to enter rural markets as opposed to arid and semi-arid ones (Models 3 and 4). Controlling for that tendency, however, population density is negatively and significantly associated with branch penetration for Equity but not for other banks. This is similar to the result for the full sample of districts and again indicates that Equity was more willing to serve sparsely populated areas than other banks.

Models 3 and 4 also indicate that Equity Bank's branch expansion into non-urban districts was more forceful than that for the other banks. For Equity Bank, the coefficient for the 2009 dummy variable is almost as large for the non-urban sample (Model 4) as it is for the full sample (Model 2). For other banks, the coefficient for the 2009 dummy variable is much smaller for the non-urban sample (Model 3) than for the full sample (Model 1). In addition, the intercept/constant of the regression models remains much larger for Equity's branching than for other banks, even in non-urban areas (Models 1-4). This shows Equity Bank's greater general tendency to open branches regardless of district characteristics. Moreover, the ratio of Equity Bank's intercept/constant to that of the others in the non-urban areas (Models 3 and 4) is much larger than the same ratio for the full sample (Models 1 and 2). This too shows that Equity Bank went more heavily into non-urban districts than other banks.

By interacting the district characteristics with the 2009 dummy variable, we get a better sense of the types of districts that Equity Bank was entering between 2006 and 2009. The interactions between the 2009 dummy variable and the language variables are positive and significant (Model 9). While the negative coefficients for minority dialects and Swahili speakers are larger (in absolute value) than the coefficients on the interactions, the positive coefficients on the interactions do indicate that Equity 
Bank moved toward serving non-English speakers from 2006 to 2009. A similar pattern holds for non-Equity bank branches (Model 6), but: (a) the coefficients on the interactions are much smaller than for Equity, and (b) the ratio of the (absolute value of the) coefficient for the language dummies to the coefficient for the interactions is much larger for the non-Equity sample. Therefore, it appears that Equity Bank moved more toward non-English speakers than other banks.

The interaction between the 2009 dummy variable and population density is positive and significant for Equity Bank (Model 8), but it is smaller in absolute value than the coefficient for population density, and the joint effect is not significantly different from zero, indicating that Equity Bank does not favor densely populated districts. Also, when we include the interactions for the language variables and population density together (Model 10), the population density interaction is no longer significant, indicating that the negative relationship between population density and branching still holds for Equity Bank from 2006 to 2009. In the non-Equity Bank sample, there is never a significant negative relationship between population density and branching, regardless of the specification.

Thus, the overall evidence suggests that Equity Bank's branching strategies are different from those of other banks; such branching patterns suggest that Equity Bank was promoting financial inclusion during the period of 2006-2009. Below we look at the role of Equity Bank in bank penetration and access to banking services.

\section{IV.2 Bank Penetration and Financial Access: A Closer Look at Equity Bank}

Our previous results suggest that Equity Bank has pursued different branching strategies from other commercial banks. Our next step is to explore whether its expansion strategy has led to different effects on households' access to banking services. Table 5 reports the marginal effects when estimating our Probit model of households' access to banking services (Eq. 2) by maximum likelihood with standard errors clustered by district and year (see Petersen, 2009). We report first a regression with household characteristics, district level bank branch expansion by other banks and district fixed effects (Model 1). Next, we differentiate banks by their ownership structure (i.e. foreign banks, government banks and domestic private banks). We run these regressions with and without the dummy variable associated with Equity Bank presence (Models 2 and 3). Finally, instead of using an indicator denoting the presence of a certain type of bank, we use the number of branches for 
each bank ownership type. Again, we run these regressions with and without the dummy variable associated with Equity Bank presence (Models 4 and 5).

Table 5 shows, first, that the presence of Equity Bank in a specific district is strongly positively related to the residents' probability of having a bank account, which goes beyond the effect of bank expansion and presence of other commercial banks (Models 1, 3 and 5). This effect is highly statistically significant regardless of the model specification. The coefficients suggest that the penetration of Equity Bank in a new district increases the probability of having a bank account by 24 percentage points. As noted, according to the FinAccess survey, the proportion of people having a bank account in Kenya was 14 percent in 2006 and 23 percent in 2009. Therefore, the magnitude associated with Equity Bank presence on financial access is also economically significant. This finding is consistent with the notion that the business model of Equity Bank, which targeted middleand low-income segments of the population using such strategies as the local language requirement in its branches, has paid off in terms of greater financial inclusion.

Second, we find that the presence of domestic private banks (including Equity), government banks or foreign banks all have a positive impact on access to bank accounts at the district level (Model 2). However, we find a hierarchy in the effects of different types of banks: the effect of foreign banks is 3 percent, the effect of government banks is 4 percent, and the effect of domestic private banks is 5 percent. A potential explanation for these differences is that while domestic private banks have followed a strategy of targeting all segments of the population, foreign banks traditionally have targeted the high-income segment of the population. This is consistent with Beck and Brown (2011)'s finding that foreign banks may cherry-pick their clients among households in transition economies. These strategies are reflected in the differential requirements for opening a bank account.

Third, the number of bank branches by district, a measure of banking sector outreach and competition, appears to be an important determinant of usage of banking services. The coefficient on the total number of bank branches is positive and highly statistically significant (Model 1). Moreover, the results suggest that the positive impact of a new branch is stronger for foreign banks (Models 4 and 5).

Most of the control variables come in significantly in the expected directions. For example, females 
and individuals with large families and with no knowledge of English are less likely to have a bank account, while education, wealth (measured by an asset score), house ownership, age and income stability (i.e. salaried workers) are positively related to having a bank account. The overall fit of our model is good, with the Pseudo $\mathrm{R}^{2}$ around 0.33 in all our specifications. ${ }^{9}$

\section{IV.3 Addressing Potential Endogeneity Problems}

As discussed earlier, there are potential endogeneity problems arising from non-random bank branching expansion. We use an Instrumental Variables (IV) approach to address the endogeneity issue. Table 6 reports the results from our two-stage IV procedures; the instruments are the proportion of people speaking a minority language (not English or Swahili) in a given district and its interaction with the 2009 dummy. The appropriateness of these instruments is discussed in detail in the earlier section, and it is reasonable that the minority language proportion does not directly affect the outcome for access to banking. We estimate IV GMM and IV Probit models for our baseline regression reported in Model 1 of Table 5. ${ }^{10}$ The results from the second-stage (Models 1, 3 and 4 of Table 6) indicate that the impact of Equity Bank presence on the probability of having a bank account remains positive and highly statistically significant. The main difference with our baseline Probit estimator is that the magnitude of the coefficient increases from 0.04 (Table 5) to 0.09, which suggests an attenuation bias in our baseline Probit estimates. This is consistent with the premise that if more underdeveloped districts are less effective at providing access to finance, the baseline Probit estimates would underestimate the true impact of Equity Bank branch expansion.

The results from the first-stage (columns 2 and 5) confirm results obtained from Table 4 and suggest that Equity Bank altered its branching policy in the period 2006-2009. The negative coefficient on the district-level proportion of people speaking minority languages and the positive coefficient on the interaction between people speaking minority languages and a 2009 dummy variable suggest that Equity Bank moved toward serving minority language speaking districts. The table also presents the $p$-values for the Partial R-squared of excluded instruments and Hansen's $J$ test of over-identifying restrictions (e.g., Baum, Schaffer and Stillman, 2003). The R-squared of the excluded instruments

\footnotetext{
9 These results are also consistent with international evidence on the determinants of the use of bank services. See, for example, Beck and Brown (2011).

${ }^{10}$ In unreported regressions, we also conduct our IV approach for all our specifications. The main result in this paper remains qualitatively unchanged regardless of the specification that we choose.
} 
indicates that the instruments and endogenous variables are correlated, even after netting out the effects of all other exogenous variables. And, the $J$ test cannot reject the null hypothesis that all the instruments are valid. These results are consistent with the validity of the instruments for Equity Bank's branching strategies. Overall, the results in Table 6 suggest that the positive impact of Equity on access to banking services is robust to controlling for potential endogeneity bias.

\section{IV.4 Some Extensions}

\section{a. Who Benefits from Banking Services?: The Case of Equity Bank}

Until now we have presented evidence consistent with the propositions that Equity Bank's branch strategy has targeted under-served geographic areas and had a substantial impact on access to banking services in Kenya. Specifically, the results in our previous section suggest that Kenyans residing in districts in which Equity Bank started operations have a higher probability of having a bank account. Since Equity Bank's business model is based, at least in part, on providing financial services to the rural poor, we would expect the impact of its presence to be stronger for the underprivileged segments of the population (in terms of physical and human capital and income stability).

With this idea in mind, Table 7 explores potential heterogeneities in the impact of Equity Bank presence on the probability of having a bank account. In particular, Models 1 to 4 augment our baseline regression in Table 5 with four interaction terms respectively: the interaction of the Equity Bank presence dummy with a score for the ownership of a set of physical assets, a dummy indicating if the individual is a homeowner, a dummy indicating whether the individual has a secondary and/or tertiary education level and a dummy indicating whether the individual has a salaried job. All the coefficients associated with the interactions terms have a negative sign and are highly significant, suggesting that the impact of Equity Bank on access to banking services is, indeed, heterogeneous across individuals with different characteristics. It is stronger for Kenyans with less wealth, without their own permanent house, without secondary and/or tertiary education and without a salaried job. Therefore, these results are consistent with Equity Bank's mission of extending financial services to the population segments generally ignored by traditional commercial banks. Finally, it is worth noting that all the main results and the signs of the coefficients associated with the new interaction terms remain unchanged when all the interactions terms are included at the same time (Model 5). 


\section{b. Access to Credit}

We expand our baseline results to consider the impact of Equity Bank presence and bank penetration on the probability of having a loan from a bank. Table 8 reports the coefficients and marginal effects from an Ordered Probit model of usage of banking services. Our dependent variable takes the value " 0 " if the individual does not have either a bank account or a loan from a bank, the value "1" if the individual has a bank account, and the value "2" if the individual has a loan from a bank. The results indicate that Equity Bank presence increases the probability of both having a bank account (column 3) and a bank loan (column 4). In line with our baseline results in Table 5, Equity Bank presence increases by almost 4 percentage points the probability of having a bank account, and by 1 percentage point the probability of having a bank loan. These effects are statistically significant even after controlling for individual characteristics, district fixed effects and branch expansion by other banks at the district level.

\section{IV.5 Robustness Checks}

\section{a. Rural and Arid and Semi-Arid Districts}

Since bank expansions are likely to be nonrandom with banks favoring opening branches in more developed urban areas, we replicate our main results excluding urban districts (i.e., Nairobi and Mombasa) from the sample to ensure that the higher degree of development does not bias the results. These regressions are reported in Table 9. The results remain qualitatively unchanged, with the impact of Equity's presence on the probability of having a bank account still positive and highly statistically significant, though somewhat smaller than in our baseline results. However, given that the share of the population with bank accounts tends to be much lower outside Nairobi and Mombasa, the 2.5 percentage point increase in bank account usage in rural and arid and semi-arid districts still indicates a substantial impact of Equity Bank branching.

\section{b. Difference-in-Differences Estimator}

Table 10 presents the results from our difference-in-differences estimator for the probability of having a bank account. This table replicates the specifications in Models 1, 3 and 5 in Table 5, using only a subsample of districts without the presence of Equity Bank in 2006 and including time fixed effects in our baseline specification. Therefore, the coefficients reported in the table indicate the 
change in the probability of having a bank account in districts where Equity Bank started operations between 2006 and 2009 relative to districts without Equity Bank presence during the same period. The results suggest that the impact of the penetration of Equity Bank in a new district on the probability of having a bank account remains positive and highly statistically significant. The main difference with our baseline results is that the magnitude of the impact decreases slightly from 4 percentage points (Model 1 in Table 5) to 3 (Model 1 in Table 10).

\section{IV.6 Interpretations and Limitations}

Our empirical results have shown that Equity Bank pursues distinct branching and business strategies from other commercial banks operating in Kenya. In particular, it pursues financial inclusion by targeting underdeveloped areas and less privileged households while maintaining the for-profit goals of a commercial bank. We have also shown that these strategies have had impact on financial access, as the presence of Equity Bank has a positive and significant effect on the likelihood of households having access to banking services. Based on these results we conclude that Equity Bank's business model and success can be a solution to the financial access problem that has impeded the development of inclusive financial sectors in many African countries.

A potential concern regarding the interpretation of our results is that Equity Bank might not have actively pursued financial inclusion by entering underdeveloped areas. Rather, our main result could be accounted for by either demand side factors (e.g., more developed areas have more demand for financial services) or by Equity Bank's anticipation of growth opportunities in certain areas that they hope to capture by opening new branches ahead of other banks. We note that even if such alternative interpretations hold, Equity Bank seems to have seized upon these opportunities more quickly than other banks and, regardless of Equity's motivation, the end result has been greater financial inclusion.

Throughout the paper we have also provided a series of checks to help rule out competing interpretations. First, we employ the IV approach to address the nonrandom branching decisions of Equity Bank with instruments that capture differences in branching strategies between Equity and other banks; we continue to find similar (in fact, stronger) results. Second, we find that Equity Bank presence not only increased the likelihood of a household having a bank account, but also the 
chances of obtaining a loan from a bank (though the effect on this latter banking service is weaker, as fractions of households having bank loans remain low in most underdeveloped areas).

We have limited ourselves to the question of whether Equity Bank's branch expansion led to greater financial inclusion. We acknowledge, however, that provision of financial services on the scale of Equity Bank raises a host of additional issues that we do not address. For example, having over half of all bank accounts in a country in the hands of a single institution could raise concerns about the stability of the Kenyan banking system. While the bank accounts are individually small, they are vital to account owners with limited means. Such a concentration of bank accounts is likely to pose challenges for the deposit insurance system. Even if the system has the funds to cover a potential Equity Bank failure, any delay in accessing deposits by account owners as the failure is resolved poses its own set of stability issues.

Equity Bank's expansion into other countries also raises the possibility that poor financial performance in other markets could jeopardize the safety of Kenyans' deposits. Encouraging competition for this market segment could help alleviate concerns about the concentration of deposits and accounts, but it raises additional issues regarding stability. Clearly, competition among micro-lenders in Andhra Pradesh and the over-indebtedness of many poor borrowers has contributed to the recent instability in Indian microfinance. All of these issues are worthy of investigation, but we leave this to future research.

This also leads to the question of what is the role of financial inclusion in promoting economic growth. Simply expanding banking services to poor areas and population does not guarantee that the funds will be used properly (e.g., in spawning entrepreneurial activities) and loans repaid. This has been shown by the uneven successes of many microfinance institutions in developing countries. To this point, the gains in financial inclusions spurred by Equity Bank have focused primarily on bank accounts. In the future, however, it seems likely that provision of credit on a wider scale will be more lucrative than expanding provision of savings services. Although Equity Bank has been financially successful thus far (as reflected in their books and stock performance), it remains to be seen whether the bank's model is sustainable over the long term and whether it can be applied successfully in other African countries. 


\section{Conclusions}

Although Sub-Saharan African countries have implemented an extensive package of economic and financial sector reforms over the last few decades, many of these countries still face a severe financial development gap relative not only to the advanced economies but also to other peer developing economies. A key obstacle to financial development is the access of the unprivileged segments of the population to finance, which would promote economic growth at the broadest scale. In view of the important role of financial inclusion in developing countries, in this paper we study the expansion strategies of Equity Bank and other banks, and their impact on access to banking services in Kenya.

The experience of Equity Bank in Kenya offers an interesting 'laboratory' for the study of financial access for two reasons. First, the branch banking network in Kenya has experienced rapid growth in recent years. Second, this bank expansion has been led by Equity Bank, a pioneering institution that devised a banking service strategy targeting low income clients and traditionally under-served geographic areas.

Taking advantage of the time dimension of our dataset to facilitate identification, we exploit the within-district variation in Kenyans' access to banking services and a shift in the expansion policy of Equity Bank. We find that branch expansion in the period 2006-2009 is strongly associated with greater financial access in Kenya. Most importantly, the analysis is consistent with the notion that Equity Bank has had a significant effect in enhancing households' access to bank accounts and bank credit, especially for individuals in households with low income, without their own permanent house, with less education, and without a salaried job. These results highlight the importance of institutions, such as Equity Bank, with a business model focused on the provision of financial services to the population segments ignored by traditional commercial banks while generating sustainable profits in the process. Such institutions could be an important part of the solution to the financial access problem that has hindered the development of inclusive financial sectors in many developing countries. 


\section{References}

Allen, Franklin, Elena Carletti, Robert Cull, Jun Qian, and Patricio Valenzuela, 2012, Resolving the African development gap: Cross-country comparisons and a within-country study of Kenya, forthcoming in S. Edwards, S. Johnson, and D. Weil, eds: NBER Volume on African Economic Successes (University of Chicago Press).

Allen, Franklin, Isaac Otchere, and Lemma Senbet, 2011, African financial systems: A review, Review of Development Finance 1, 79-113.

Ashraf, Nava, Dean Karlan, and Wesley Yin. 2006, Tying odysseus to the mast: Evidence from a commitment savings product in the Phillippines, Quarterly Journal of Economics 121, 673-697.

Banerjee, Abhijit, Esther Duflo, Rachel Glennerster and Cynthia Kinnan, 2010, The miracle of microfinance? Evidence from a randomized evaluation, Working paper, MIT.

Baum, Christopher F., Mark E. Schaffer and Steven Stillman, 2003. "Instrumental variables and GMM: Estimation and testing," Stata Journal, StataCorp LP, vol. 3(1), pages 1-31, March.

Beck, Thorsten, and Martin Brown, 2011, Which households use banks? Evidence from the transition economies, Working paper 1295, European Central Bank.

Beck, Thorsten, Robert Cull, Michael Fuchs, Jared Getenga, Peter Gatere, John Randa, and Mircea Trandafir, 2010. "Banking Sector Stability, Efficiency, and Outreach in Kenya," in Christopher S. Adam, Paul Collier, and Njuguna S. Ndung'u, eds., Kenya: Policies for Prosperity, Oxford: Oxford University Press.

Beck, Thorsten, Asli Demirgüç-Kunt, and Ross Levine. 2007, Finance, inequality, and the poor, Journal of Economic Growth 12, 27-49.

Beck, Thorsten, Asli Demirgüç-Kunt, and Maria Soledad Martinez Peria, 2007, Reaching out: Access to and use of banking services across countries, Journal of Financial Economics 85, 234-266.

Beck, Thorsten, Asli Demirgüç-Kunt, and Maria Soledad Martinez Peria, 2008, Banking services for everyone? Barriers to bank access and use around the world, World Bank Economic Review 22, 397-430.

Beck, Thorsten, Samuel Munzele Maimbo, Issa Faye, and Thouraya Triki, 2011. "Financing Africa: Through the Crisis and Beyond.” Washington, DC: World Bank.

Berger, Allen N., George R.G. Clarke, Robert Cull, Leora Klapper, and Gregory F. Udell, 2005, Corporate governance and bank performance: A joint analysis of the static, selection, and dynamic effects of domestic, foreign, and state ownership, Journal of Banking and Finance 29, 2179-2221.

Bruhn, Miriam and Inessa Love, 2009, The economic impact of banking the unbanked: Evidence from Mexico, Policy Research Working Paper 4981, World Bank.

Brune, Lasse, Xavier Giné, Jessica Goldberg, Dean Yang. 2011, Commitments to save: A field experiment in rural Malawi, Manuscript, University of Michigan.

Burgess, Robin, Rohini Pande, 2005, Do rural banks matter? Evidence from the Indian social banking experiment, American Economic Review 95, 780-795.

Chaia, Alberto, Aparna Dalal, Tony Goland, Maria Jose Gonzalez, Jonathan Morduch, and Robert Schiff, 2011, Half the world is unbanked, Working paper, New York University.

Clarke, George R.G., L. Colin Xu, and Heng-Fu Zou, 2006, Finance and income inequality: What do the data tell us?, Southern Economic Journal 72, 578-596.

Collins, Daryl, Jonathan Morduch, Stuart Rutherford, and Orlanda Ruthven, 2009, Portfolios of the Poor: How the World's Poor Live on $\$ 2$ a Day (Princeton University Press, Princeton, NJ)

Dupas, Pascaline, and Jonathan Robinson, 2009, Savings constraints and microenterprise development: Evidence from a field experiment in Kenya, Working Paper 14693, NBER. 
Dupas, Pascaline, Anthony Keats, Sarah Green, and Jonathan Robinson, 2012, Challenges in banking the rural poor: Evidence from Kenya's western province, Working Paper 17851, NBER.

Honohan, Patrick, 2008, Cross-Country variation in household access to financial services, Journal of Banking and Finance 32, 2493-2500.

Karlan, Dean and Jonathan Zinman, 2010, Expanding microenterprise credit access: Using randomized supply decisions to estimate the impacts in Manila, Working paper, Yale University.

Karlan, Dean and Jonathan Zinman. 2011, Microcredit in theory and practice: Using randomized credit scoring for impact evaluation, Science 332, 1278-1284.

Kendall, Jake, Nataliya Mylenko and Alejandro Ponce, 2010, Measuring financial access around the world, Policy Research Working Paper 5253, World Bank.

Levine, Ross, 2005, Finance and growth: Theory and evidence, in Philippe Aghion and Steven Durlauf, eds.: Handbook of Economic Growth (Elsevier Science, Amsterdam).

Mbiti, Isaac and David N. Weil, 2011, Mobile banking: The impact of M-Pesa in Kenya, Working Paper 17129, NBER.

Ncube, Mthuli and Lemma Senbet, 1997, Perspectives on financial regulation and liberalization in Africa under incentive problems and asymmetric information, Journal of African Economies 6, 29-88.

Petersen, Mitchell, 2009, Estimating standard errors in finance panel data sets: Comparing approaches, Review of Financial Studies 22, 435-480.

Rajan, Raghuram and Luigi Zingales, 1998, Financial dependence and growth, American Economic Review 88, 559-586.

Ravallion, Martin, 2009, Should the randomistas rule? The Economists' Voice, 6, 1-5.

World Bank, 2007, Finance for all? Policies and pitfalls in expanding access, Policy Research Report, Washington, DC. 


\section{Table 1}

\section{Bank Branches over Time by Bank Name and Ownership}

This table reports the number of Kenyan bank branches by bank name and ownership for 2006 and 2009, based on alternative data sources, including phone calls, official websites, banks' annual reports and government publications.

\begin{tabular}{|c|c|c|c|c|c|}
\hline No & Domestic private banks & 2006 & 2009 & Change & $\%$ Change \\
\hline 1 & African Banking Corporation Ltd. & 8 & 10 & 2 & 25 \\
\hline 2 & CharterHouse Bank Ltd. & 10 & 10 & 0 & 0 \\
\hline 3 & Chase Bank Kenya Ltd. & 2 & 12 & 10 & 500 \\
\hline 4 & City Finance Bank Ltd. & 1 & 1 & 0 & 0 \\
\hline 5 & Commercial Bank of Africa Ltd. & 19 & 20 & 1 & 5 \\
\hline 6 & Co-operative Bank of Kenya Ltd. & 52 & 83 & 31 & 60 \\
\hline 7 & Credit Bank Ltd. & 4 & 5 & 1 & 25 \\
\hline 8 & Diamond Trust Bank of Kenya Ltd. & 8 & 32 & 24 & 300 \\
\hline 9 & Dubai Bank Ltd. & 4 & 4 & 0 & 0 \\
\hline 10 & Equatorial Commercial Bank Ltd. & 3 & 5 & 2 & 67 \\
\hline 11 & Equity Bank & 44 & 112 & 68 & 155 \\
\hline 12 & Fidelity Commercial Bank Ltd. & 5 & 7 & 2 & 40 \\
\hline 13 & FINA Bank Ltd. & 6 & 14 & 8 & 133 \\
\hline 14 & First Community Bank & 0 & 18 & 18 & - \\
\hline 15 & Giro Commercial Bank Ltd. & 6 & 8 & 2 & 33 \\
\hline 16 & Guardian Bank Ltd. & 6 & 7 & 1 & 17 \\
\hline 17 & Imperial Bank Ltd. & 6 & 13 & 7 & 117 \\
\hline 18 & Investments and Mortgages & 9 & 17 & 8 & 89 \\
\hline 19 & Middle East Bank Kenya Ltd. & 2 & 3 & 1 & 50 \\
\hline 20 & National Industrial Credit Bank Ltd. & 16 & 16 & 0 & 0 \\
\hline 21 & Oriental Commericial Bank Ltd. & 4 & 8 & 4 & 100 \\
\hline 22 & Paramount Universal Bank Ltd. & 4 & 7 & 3 & 75 \\
\hline 23 & Prime Bank Ltd. & 9 & 14 & 5 & 56 \\
\hline 24 & Southern Credit Banking Corporation Ltd. & 9 & 10 & 1 & 11 \\
\hline 25 & Trans-National Bank Ltd. & 9 & 13 & 4 & 44 \\
\hline \multirow[t]{2}{*}{26} & Victoria Commercial Bank Ltd. & 1 & 1 & 0 & 0 \\
\hline & Sub-Total & 247 & 450 & 203 & 82 \\
\hline No & Foreign banks & 2006 & 2009 & Change & $\%$ Change \\
\hline 1 & Bank of Africa Kenya Ltd. & 4 & 10 & 6 & 150 \\
\hline 2 & Bank of Baroda Kenya Ltd. & 7 & 9 & 2 & 29 \\
\hline 3 & Bank of India Ltd. & 4 & 5 & 1 & 25 \\
\hline 4 & Barclays Bank of Kenya Ltd. & 62 & 119 & 57 & 92 \\
\hline 5 & Citibank N.A. & 3 & 4 & 1 & 33 \\
\hline 6 & ECO BANK & 9 & 19 & 10 & 111 \\
\hline 7 & Gulf African Bank Ltd & 0 & 14 & 14 & - \\
\hline 8 & Habib Bank A.G. Zurich & 4 & 5 & 1 & 25 \\
\hline 9 & Habib Bank Ltd. & 4 & 4 & 0 & 0 \\
\hline 10 & K-Rep Bank Ltd. & 22 & 30 & 8 & 36 \\
\hline 11 & Standard Chartered Bank Kenya Ltd. & 31 & 35 & 4 & 13 \\
\hline \multirow[t]{2}{*}{12} & UBA & 0 & 4 & 4 & - \\
\hline & Sub-Total & 150 & 258 & 108 & 72 \\
\hline No & Government and government-influenced banks & 2006 & 2009 & Change & $\%$ Change \\
\hline 1 & CFC Stanbic Bank Ltd. & 16 & 35 & 19 & 119 \\
\hline 2 & Consolidated Bank of Kenya Ltd. & 12 & 13 & 1 & 8 \\
\hline 3 & Development Bank of Kenya Ltd. & 1 & 2 & 1 & 100 \\
\hline 4 & Kenya Commercial Bank Ltd. & 117 & 169 & 52 & 44 \\
\hline \multirow[t]{3}{*}{5} & National Bank of Kenya Ltd. & 33 & 43 & 10 & 30 \\
\hline & Sub-Total & 179 & 262 & 83 & 46 \\
\hline & Total & 576 & 970 & 394 & 68 \\
\hline
\end{tabular}




\section{Table 2}

\section{Descriptive Statistics, District Level}

This table reports descriptive statistics for all variables used in this study at the district level, based on 2006 and 2009 FinAccess surveys, 1999 Kenyan census and alternative data sources, including phone calls, official websites, banks' annual reports and government publications.

\begin{tabular}{|c|c|c|c|c|c|c|c|c|c|}
\hline$\overline{\text { District }}$ & $\begin{array}{c}\text { Bank branches } \\
(2006)\end{array}$ & $\begin{array}{c}\text { Bank branches } \\
(2009)\end{array}$ & Swahili (2006) & $\begin{array}{c}\text { Minority } \\
\text { Language } \\
\text { (2006) }\end{array}$ & Urban & Rural & $\begin{array}{l}\text { Arid and } \\
\text { Semi-Arid }\end{array}$ & Area (km2) & $\begin{array}{c}\text { Population } \\
\text { (1999) }\end{array}$ \\
\hline Baringo & 3 & 4 & 0.65 & 0.27 & 0 & 0 & 1 & 8,646 & 264,978 \\
\hline Bomet & 2 & 4 & 0.44 & 0.50 & 0 & 1 & 0 & 1,882 & 382,794 \\
\hline Bondo & 0 & 2 & 0.10 & 0.88 & 0 & 1 & 0 & 987 & 238,780 \\
\hline Bungoma & 8 & 12 & 0.64 & 0.29 & 0 & 1 & 0 & 2,069 & 876,491 \\
\hline Buret & 1 & 3 & 0.52 & 0.42 & 0 & 1 & 0 & 955 & 316,882 \\
\hline Busia & 3 & 6 & 0.68 & 0.32 & 0 & 1 & 0 & 1,124 & 370,608 \\
\hline Butere Mumias & 1 & 4 & 0.70 & 0.27 & 0 & 1 & 0 & 939 & 476,928 \\
\hline Embu & 6 & 8 & 0.34 & 0.58 & 0 & 0 & 1 & 729 & 278,196 \\
\hline Garissa & 1 & 8 & 0.02 & 0.98 & 0 & 0 & 1 & 44,952 & 329,939 \\
\hline Gucha & 0 & 0 & 0.33 & 0.59 & 0 & 1 & 0 & 661 & 460,939 \\
\hline Homa Bay & 5 & 6 & 0.08 & 0.90 & 0 & 1 & 0 & 1,160 & 288,540 \\
\hline Isiolo & 2 & 5 & 0.73 & 0.23 & 0 & 0 & 1 & 25,698 & 100,861 \\
\hline Kajiado & 6 & 21 & 0.83 & 0.03 & 0 & 0 & 1 & 21,903 & 406,054 \\
\hline Kakamega & 10 & 12 & 0.64 & 0.30 & 0 & 1 & 0 & 1,395 & 603,422 \\
\hline Keiyo & 1 & 0 & 0.78 & 0.13 & 0 & 0 & 1 & 1,439 & 143,865 \\
\hline Kericho & 7 & 9 & 0.59 & 0.39 & 0 & 1 & 0 & 2,111 & 468,493 \\
\hline Kiambu & 10 & 19 & 0.17 & 0.66 & 0 & 1 & 0 & 1,324 & 744,010 \\
\hline Kilifi & 5 & 11 & 1.00 & 0.00 & 0 & 1 & 0 & 4,779 & 544,303 \\
\hline Kirinyaga & 5 & 9 & 0.01 & 0.96 & 0 & 1 & 0 & 1,478 & 457,105 \\
\hline Kisii & 7 & 13 & 0.35 & 0.58 & 0 & 1 & 0 & 649 & 491,786 \\
\hline Kisumu & 20 & 31 & 0.21 & 0.66 & 0 & 1 & 0 & 919 & 504,359 \\
\hline Kitui & 3 & 7 & 0.22 & 0.78 & 0 & 0 & 1 & 20,402 & 515,422 \\
\hline Koibatek & 0 & 1 & 0.40 & 0.57 & 0 & 0 & 1 & 2,306 & 138,163 \\
\hline Kuria & 1 & 1 & 0.93 & 0.05 & 0 & 1 & 0 & 581 & 151,887 \\
\hline Kwale & 4 & 8 & 1.00 & 0.00 & 0 & 1 & 0 & 8,295 & 496,133 \\
\hline Laikipia & 7 & 13 & 0.54 & 0.26 & 0 & 1 & 0 & 9,229 & 322,187 \\
\hline Lamu & 2 & 3 & 1.00 & 0.00 & 0 & 1 & 0 & 6,167 & 72,686 \\
\hline Lugari & 0 & 0 & 0.50 & 0.35 & 0 & 1 & 0 & 670 & 215,920 \\
\hline Machakos & 9 & 16 & 0.35 & 0.53 & 0 & 1 & 0 & 6,281 & 906,644 \\
\hline Makueni & 4 & 7 & 0.29 & 0.71 & 0 & 0 & 1 & 7,966 & 771,545 \\
\hline Malindi & 4 & 11 & 1.00 & 0.00 & 0 & 1 & 0 & 7,751 & 281,552 \\
\hline Mandera & 0 & 2 & 0.00 & 1.00 & 0 & 0 & 1 & 26,744 & 250,372 \\
\hline Maragua & 0 & 0 & 0.03 & 0.83 & 0 & 1 & 0 & 868 & 387,969 \\
\hline Marakwet & 1 & 1 & 0.63 & 0.28 & 0 & 0 & 1 & 1,588 & 140,629 \\
\hline Marsabit & 1 & 2 & 0.85 & 0.13 & 0 & 0 & 1 & 61,296 & 121,478 \\
\hline Mbeere & 0 & 2 & 0.13 & 0.85 & 0 & 0 & 1 & 2,093 & 170,953 \\
\hline Meru & 19 & 31 & 0.13 & 0.83 & 0 & 1 & 0 & 8,017 & $1,300,000$ \\
\hline Migori & 2 & 5 & 0.59 & 0.39 & 0 & 1 & 0 & 2,005 & 514,897 \\
\hline Mombasa & 60 & 83 & 0.90 & 0.00 & 1 & 0 & 0 & 230 & 665,018 \\
\hline Moyale & 1 & 3 & 0.73 & 0.27 & 0 & 0 & 1 & 9,390 & 53,479 \\
\hline Mt.Elgon & 1 & 0 & 0.93 & 0.03 & 0 & 1 & 0 & 944 & 135,033 \\
\hline Murang'a & 12 & 16 & 0.07 & 0.86 & 0 & 1 & 0 & 930 & 348,304 \\
\hline Mwingi & 1 & 3 & 0.26 & 0.74 & 0 & 0 & 1 & 10,030 & 303,828 \\
\hline Nairobi & 230 & 388 & 0.58 & 0.01 & 1 & 0 & 0 & 696 & $2,100,000$ \\
\hline Nakuru & 26 & 40 & 0.58 & 0.23 & 0 & 1 & 0 & 7,242 & $1,200,000$ \\
\hline Nandi & 4 & 7 & 0.83 & 0.16 & 0 & 1 & 0 & 2,899 & 578,751 \\
\hline Narok & 4 & 6 & 0.90 & 0.04 & 0 & 0 & 1 & 15,098 & 365,750 \\
\hline Nyandarua & 4 & 6 & 0.00 & 0.93 & 0 & 1 & 0 & 3,304 & 479,902 \\
\hline Nyando & 0 & 0 & 0.10 & 0.88 & 0 & 1 & 0 & 1,168 & 299,930 \\
\hline Nyeri & 17 & 20 & 0.06 & 0.89 & 0 & 1 & 0 & 3,356 & 661,156 \\
\hline Rachuonyo & 0 & 0 & 0.06 & 0.90 & 0 & 1 & 0 & 945 & 307,126 \\
\hline Siaya & 2 & 4 & 0.11 & 0.77 & 0 & 1 & 0 & 1,520 & 480,184 \\
\hline Suba & 0 & 0 & 0.33 & 0.65 & 0 & 1 & 0 & 1,055 & 155,666 \\
\hline Taita Taveta & 3 & 11 & 0.95 & 0.00 & 0 & 1 & 0 & 17,128 & 246,671 \\
\hline Tana River & 2 & 1 & 0.98 & 0.00 & 0 & 0 & 1 & 38,446 & 180,901 \\
\hline Teso & 0 & 1 & 1.00 & 0.00 & 0 & 1 & 0 & 559 & 181,491 \\
\hline Tharaka & 0 & 0 & 0.03 & 0.97 & 0 & 0 & 1 & 1,570 & 100,992 \\
\hline Thika & 12 & 22 & 0.18 & 0.69 & 0 & 1 & 0 & 1,960 & 645,713 \\
\hline Trans-Nzoia & 9 & 15 & 0.96 & 0.01 & 0 & 1 & 0 & 2,487 & 575,662 \\
\hline Transmara & 1 & 0 & 0.73 & 0.25 & 0 & 0 & 1 & 2,846 & 170,591 \\
\hline Turkana & 2 & 3 & 0.94 & 0.06 & 0 & 0 & 1 & 68,388 & 450,860 \\
\hline Uasin Gishu & 16 & 23 & 0.78 & 0.12 & 0 & 1 & 0 & 3,328 & 622,705 \\
\hline Vihiga & 0 & 4 & 0.57 & 0.30 & 0 & 1 & 0 & 563 & 498,883 \\
\hline Wajir & 2 & 4 & 0.02 & 0.98 & 0 & 0 & 1 & 55,501 & 319,261 \\
\hline West Pokot & 1 & 1 & 0.66 & 0.34 & 0 & 0 & 1 & 9,064 & 308,086 \\
\hline
\end{tabular}


Table 3

Descriptive Statistics, Household Level

This table reports descriptive statistics for all variables used in this study at the household level, based on 2006 and 2009 FinAccess surveys.

\begin{tabular}{|c|c|c|c|c|c|c|c|c|c|c|}
\hline \multirow[b]{2}{*}{ Variable } & \multicolumn{5}{|c|}{2006} & \multicolumn{5}{|c|}{2009} \\
\hline & Obs & Mean & Std. Dev. & Min & $\operatorname{Max}$ & Obs & Mean & Std. Dev. & Min & Max \\
\hline Bank account & 4360 & 0.1420 & 0.3491 & 0 & 1 & 6562 & 0.227 & 0.419 & 0 & 1 \\
\hline Bank Loan & 4360 & 0.0290 & 0.1680 & 0 & 1 & 6562 & 0.044 & 0.204 & 0 & 1 \\
\hline Household size & 4360 & 4.4722 & 2.3382 & 1 & 16 & 6562 & 4.959 & 2.600 & 1 & 20 \\
\hline Education: Primary & 4360 & 0.3172 & 0.4654 & 0 & 1 & 6562 & 0.186 & 0.389 & 0 & 1 \\
\hline Education: Secondary & 4360 & 0.2289 & 0.4202 & 0 & 1 & 6562 & 0.124 & 0.329 & 0 & 1 \\
\hline Education: Tertiary & 4360 & 0.0234 & 0.1512 & 0 & 1 & 6562 & 0.007 & 0.082 & 0 & 1 \\
\hline Female & 4360 & 0.5585 & 0.4966 & 0 & 1 & 6562 & 0.419 & 0.493 & 0 & 1 \\
\hline Asset score & 4360 & 2.2011 & 2.1053 & 0 & 15 & 6562 & 2.723 & 2.761 & 0 & 18 \\
\hline Own permanent house & 4360 & 0.1298 & 0.3361 & 0 & 1 & 6562 & 0.186 & 0.389 & 0 & 1 \\
\hline Income type: Agriculture & 4360 & 0.4165 & 0.4930 & 0 & 1 & 6562 & 0.417 & 0.493 & 0 & 1 \\
\hline Income type: Waged & 4360 & 0.1729 & 0.3782 & 0 & 1 & 6562 & 0.152 & 0.359 & 0 & 1 \\
\hline Income type: Business & 4360 & 0.2865 & 0.4522 & 0 & 1 & 6562 & 0.286 & 0.452 & 0 & 1 \\
\hline Age group: 18-24 & 4360 & 0.2032 & 0.4024 & 0 & 1 & 6562 & 0.178 & 0.383 & 0 & 1 \\
\hline Age group: 25-34 & 4360 & 0.2837 & 0.4509 & 0 & 1 & 6562 & 0.258 & 0.438 & 0 & 1 \\
\hline Age group: 35-44 & 4360 & 0.1982 & 0.3987 & 0 & 1 & 6562 & 0.208 & 0.406 & 0 & 1 \\
\hline Age group: 45-54 & 4360 & 0.1232 & 0.3287 & 0 & 1 & 6562 & 0.134 & 0.340 & 0 & 1 \\
\hline Age group: 55+ & 4360 & 0.1459 & 0.3530 & 0 & 1 & 6562 & 0.183 & 0.387 & 0 & 1 \\
\hline Language: Swahili & 4360 & 0.4764 & 0.4995 & 0 & 1 & 6562 & 0.647 & 0.478 & 0 & 1 \\
\hline Language: Minority language & 4360 & 0.4266 & 0.4946 & 0 & 1 & 6562 & 0.231 & 0.422 & 0 & 1 \\
\hline Urban & 4360 & 0.1135 & 0.3173 & 0 & 1 & 6562 & 0.158 & 0.365 & 0 & 1 \\
\hline Rural & 4360 & 0.6564 & 0.4750 & 0 & 1 & 6562 & 0.649 & 0.477 & 0 & 1 \\
\hline Arid and Semi-Arid & 4360 & 0.2300 & 0.4209 & 0 & 1 & 6562 & 0.193 & 0.395 & 0 & 1 \\
\hline Total bank branches & 4360 & 29.3475 & 67.4684 & 0 & 230 & 6562 & 61.189 & 124.190 & 0 & 388 \\
\hline Bank branches (excluding Equity Bank) & 4360 & 27.7094 & 64.6335 & 0 & 220 & 6562 & 56.249 & 116.231 & 0 & 362 \\
\hline Equity ban branches & 4360 & 1.6381 & 2.9712 & 0 & 10 & 6562 & 4.939 & 8.093 & 0 & 26 \\
\hline Equity bank presence & 4360 & 0.477 & 0.50 & 0 & 1 & 6562 & 0.873 & 0.333 & 0 & 1 \\
\hline
\end{tabular}


Table 4

Bank Expansion Strategies

This table reports OLS estimates from a model of the number of bank branches over number of banks in each group against the variables listed below. Robust standard errors are in parentheses. Standard errors are clustered by district. $* * *, * *, *$ indicate significance at the $1 \%, 5 \%$ and $10 \%$ levels, respectively.

\begin{tabular}{|c|c|c|c|c|c|c|c|c|c|c|}
\hline \multirow{3}{*}{$\begin{array}{l}\text { Dep. variable: } \\
\text { Number of branches over number of banks }\end{array}$} & $(1)$ & (2) & (3) & (4) & $(5)$ & $(6)$ & $(7)$ & $(8)$ & $(9)$ & $(10)$ \\
\hline & \multicolumn{2}{|c|}{ Whole Sample } & \multicolumn{8}{|c|}{ Rural and Arid and Semi-Arid Districts } \\
\hline & $\begin{array}{l}\text { Equity } \\
\text { Bank } \\
\text { excluded }\end{array}$ & $\begin{array}{c}\text { Equity } \\
\text { Bank }\end{array}$ & $\begin{array}{l}\text { Equity } \\
\text { Bank } \\
\text { excluded }\end{array}$ & $\begin{array}{c}\text { Equity } \\
\text { Bank }\end{array}$ & $\begin{array}{l}\text { Equity } \\
\text { Bank } \\
\text { excluded }\end{array}$ & $\begin{array}{l}\text { Equity } \\
\text { Bank } \\
\text { excluded }\end{array}$ & $\begin{array}{l}\text { Equity } \\
\text { Bank } \\
\text { excluded }\end{array}$ & $\begin{array}{c}\text { Equity } \\
\text { Bank }\end{array}$ & $\begin{array}{c}\text { Equity } \\
\text { Bank }\end{array}$ & $\begin{array}{c}\text { Equity } \\
\text { Bank }\end{array}$ \\
\hline Rural & $\begin{array}{c}-3.403^{* *} \\
(1.413)\end{array}$ & $\begin{array}{l}-6.440 \\
(3.898)\end{array}$ & $\begin{array}{c}0.101 * * * \\
(0.038)\end{array}$ & $\begin{array}{c}0.835^{* * *} \\
(0.312)\end{array}$ & $\begin{array}{c}0.101 \text { *** } \\
(0.038)\end{array}$ & $\begin{array}{c}0.101 * * \\
(0.038)\end{array}$ & $\begin{array}{c}0.101 * * \\
(0.038)\end{array}$ & $\begin{array}{c}0.835^{* * *} \\
(0.312)\end{array}$ & $\begin{array}{c}0.834^{* * *} \\
(0.313)\end{array}$ & $\begin{array}{c}0.834 * * \\
(0.315)\end{array}$ \\
\hline Arid and Semi-Arid & $\begin{array}{c}-3.504^{* *} \\
(1.415)\end{array}$ & $\begin{array}{l}-7.276^{*} \\
(3.929)\end{array}$ & & & & & & & & \\
\hline $\log$ (Density population) & $\begin{array}{l}-0.068 \\
(0.045)\end{array}$ & $\begin{array}{c}-0.311^{* *} \\
(0.134)\end{array}$ & $\begin{array}{l}-0.015 \\
(0.013)\end{array}$ & $\begin{array}{c}-0.166^{* *} \\
(0.076)\end{array}$ & $\begin{array}{l}-0.021 \\
(0.013)\end{array}$ & $\begin{array}{l}-0.015 \\
(0.013)\end{array}$ & $\begin{array}{l}-0.019 \\
(0.013)\end{array}$ & $\begin{array}{c}-0.248^{* * *} \\
(0.078)\end{array}$ & $\begin{array}{c}-0.166^{* *} \\
(0.076)\end{array}$ & $\begin{array}{c}-0.191 * * \\
(0.084)\end{array}$ \\
\hline Minority language & $\begin{array}{c}-4.961 * * \\
(2.283)\end{array}$ & $\begin{array}{c}-17.880^{* * *} \\
(6.334)\end{array}$ & $\begin{array}{c}-1.115^{* *} \\
(0.493)\end{array}$ & $\begin{array}{c}-7.328 * * * \\
(2.735)\end{array}$ & $\begin{array}{c}-1.115^{* *} \\
(0.493)\end{array}$ & $\begin{array}{c}-1.137 * * \\
(0.495)\end{array}$ & $\begin{array}{c}-1.119 * * \\
(0.492)\end{array}$ & $\begin{array}{c}-7.329 * * * \\
(2.735)\end{array}$ & $\begin{array}{c}-7.817 * * * \\
(2.731)\end{array}$ & $\begin{array}{c}-7.685^{* * *} \\
(2.718)\end{array}$ \\
\hline Swahili & $\begin{array}{c}-5.047^{* *} \\
(2.325)\end{array}$ & $\begin{array}{c}-18.666^{* * *} \\
(6.452)\end{array}$ & $\begin{array}{c}-1.130^{* *} \\
(0.489)\end{array}$ & $\begin{array}{c}-7.921 * * * \\
(2.684)\end{array}$ & $\begin{array}{c}-1.130^{* *} \\
(0.489)\end{array}$ & $\begin{array}{c}-1.161 * * \\
(0.492)\end{array}$ & $\begin{array}{c}-1.146^{* *} \\
(0.490)\end{array}$ & $\begin{array}{c}-7.922^{* * *} \\
(2.685)\end{array}$ & $\begin{array}{c}-8.299 * * * \\
(2.768)\end{array}$ & $\begin{array}{c}-8.194 * * * \\
(2.762)\end{array}$ \\
\hline Dummy(2009) & $\begin{array}{c}0.101^{* *} \\
(0.046)\end{array}$ & $\begin{array}{c}1.045^{* * *} \\
(0.282)\end{array}$ & $\begin{array}{c}0.053^{* * *} \\
(0.008)\end{array}$ & $\begin{array}{c}0.828^{* * *} \\
(0.152)\end{array}$ & & & & & & \\
\hline $\log ($ Density population) x Dummy(2009) & & & & & $\begin{array}{c}0.011 \text { *** } \\
(0.002)\end{array}$ & & $\begin{array}{c}0.007 \\
(0.005)\end{array}$ & $\begin{array}{c}0.164 * * * \\
(0.031)\end{array}$ & & $\begin{array}{c}0.049 \\
(0.077)\end{array}$ \\
\hline Minority language x Dummy(2009) & & & & & & $\begin{array}{c}0.045^{* * *} \\
(0.014)\end{array}$ & $\begin{array}{c}0.009 \\
(0.028)\end{array}$ & & $\begin{array}{c}0.971 * * * \\
(0.258)\end{array}$ & $\begin{array}{c}0.708^{* *} \\
(0.310)\end{array}$ \\
\hline Swahili x Dummy(2009) & & & & & & $\begin{array}{c}0.064 * * * \\
(0.016)\end{array}$ & $\begin{array}{c}0.035 \\
(0.026)\end{array}$ & & $\begin{array}{c}0.745^{* * *} \\
(0.275)\end{array}$ & $\begin{array}{c}0.539 \\
(0.484)\end{array}$ \\
\hline Constant & $\begin{array}{c}8.567^{* * *} \\
(2.425)\end{array}$ & $\begin{array}{c}25.869 * * * \\
(6.585)\end{array}$ & $\begin{array}{l}1.167 * * \\
(0.490)\end{array}$ & $\begin{array}{c}7.948^{* * *} \\
(2.676)\end{array}$ & $\begin{array}{l}1.194 * * \\
(0.491)\end{array}$ & $\begin{array}{c}1.194^{* *} \\
(0.493)\end{array}$ & $\begin{array}{c}1.193^{* *} \\
(0.495)\end{array}$ & $\begin{array}{c}8.362^{* * *} \\
(2.712)\end{array}$ & $\begin{array}{c}8.366^{* * *} \\
(2.720)\end{array}$ & $\begin{array}{c}8.364^{* * *} \\
(2.731)\end{array}$ \\
\hline Observations & 129 & 129 & 125 & 125 & 125 & 125 & 125 & 125 & 125 & 125 \\
\hline Adjusted R-squared & 0.748 & 0.524 & 0.230 & 0.219 & 0.229 & 0.223 & 0.217 & 0.211 & 0.209 & 0.204 \\
\hline
\end{tabular}




\section{Table 5}

\section{Access to Banking Services and Bank Presence}

This table reports estimates from a Probit model of the probability of having a bank account against the variables listed below. The data consists of 4,360 individual interviewed in 2006 and 6,562 individual in 2009. Robust standard errors are in parentheses. Standard errors are clustered by district-year groups. ${ }^{* * *}, * *, *$ indicate significance at the $1 \%, 5 \%$ and $10 \%$ levels, respectively.

\begin{tabular}{|c|c|c|c|c|c|}
\hline Dep. variable: Bank account & $(1)$ & $(2)$ & (3) & (4) & (5) \\
\hline Household size & $\begin{array}{c}-0.0060^{* * *} \\
(0.0017)\end{array}$ & $\begin{array}{c}-0.0057 * * * \\
(0.0017)\end{array}$ & $\begin{array}{c}-0.0058^{* * *} \\
(0.0017)\end{array}$ & $\begin{array}{c}-0.0056^{* * *} \\
(0.0017)\end{array}$ & $\begin{array}{c}-0.0060 * * * \\
(0.0017)\end{array}$ \\
\hline Education: Primary & $\begin{array}{c}0.0006 \\
(0.0124)\end{array}$ & $\begin{array}{l}-0.0086 \\
(0.0135)\end{array}$ & $\begin{array}{l}-0.0072 \\
(0.0138)\end{array}$ & $\begin{array}{l}-0.0004 \\
(0.0122)\end{array}$ & $\begin{array}{c}0.0030 \\
(0.0127)\end{array}$ \\
\hline Education: Secondary & $\begin{array}{c}0.1181 \text { *** } \\
(0.0217)\end{array}$ & $\begin{array}{c}0.0971 \text { *** } \\
(0.0192)\end{array}$ & $\begin{array}{c}0.0992^{* * *} \\
(0.0197)\end{array}$ & $\begin{array}{c}0.1158^{* * *} \\
(0.0215)\end{array}$ & $\begin{array}{c}0.1210^{* * * *} \\
(0.0224)\end{array}$ \\
\hline Education: Tertiary & $\begin{array}{c}0.2886^{* * *} \\
(0.0490)\end{array}$ & $\begin{array}{c}0.2161^{* * *} \\
(0.0619)\end{array}$ & $\begin{array}{c}0.2198^{* * *} \\
(0.0628)\end{array}$ & $\begin{array}{c}0.2787 * * * \\
(0.0489)\end{array}$ & $\begin{array}{c}0.2896^{* * *} \\
(0.0496)\end{array}$ \\
\hline Female & $\begin{array}{c}-0.0572 * * * \\
(0.0069)\end{array}$ & $\begin{array}{c}-0.0565 * * * \\
(0.0074)\end{array}$ & $\begin{array}{c}-0.0564^{* * *} \\
(0.0074)\end{array}$ & $\begin{array}{c}-0.0574 * * * \\
(0.0069)\end{array}$ & $\begin{array}{c}-0.0568^{* * *} \\
(0.0069)\end{array}$ \\
\hline Asset score & $\begin{array}{c}0.0283 * * * \\
(0.0047)\end{array}$ & $\begin{array}{c}0.0295^{* * *} \\
(0.0041)\end{array}$ & $\begin{array}{c}0.0294 * * * \\
(0.0040)\end{array}$ & $\begin{array}{c}0.0283 * * * \\
(0.0047)\end{array}$ & $\begin{array}{c}0.0281 \text { *** } \\
(0.0046)\end{array}$ \\
\hline Own permanent house & $\begin{array}{c}0.0531 * * * \\
(0.0155)\end{array}$ & $\begin{array}{c}0.0499 * * * \\
(0.0157)\end{array}$ & $\begin{array}{c}0.0499 * * * \\
(0.0157)\end{array}$ & $\begin{array}{c}0.0522 * * * \\
(0.0157)\end{array}$ & $\begin{array}{c}0.0516^{* * *} \\
(0.0156)\end{array}$ \\
\hline Income type: Agriculture & $\begin{array}{c}0.0330 * * \\
(0.0143)\end{array}$ & $\begin{array}{c}0.0264 * \\
(0.0141)\end{array}$ & $\begin{array}{c}0.0266^{*} \\
(0.0141)\end{array}$ & $\begin{array}{c}0.0320 * * \\
(0.0142)\end{array}$ & $\begin{array}{c}0.0324^{* *} \\
(0.0142)\end{array}$ \\
\hline Income type: Waged & $\begin{array}{c}0.2152^{* * *} \\
(0.0254)\end{array}$ & $\begin{array}{c}0.2032^{* * *} \\
(0.0266)\end{array}$ & $\begin{array}{c}0.2045^{* * *} \\
(0.0269)\end{array}$ & $\begin{array}{c}0.2136^{* * *} \\
(0.0249)\end{array}$ & $\begin{array}{c}0.2158^{* * *} \\
(0.0253)\end{array}$ \\
\hline Income type: Business & $\begin{array}{c}0.1512^{* * *} \\
(0.0191)\end{array}$ & $\begin{array}{c}0.1446^{* * *} \\
(0.0174)\end{array}$ & $\begin{array}{c}0.1446^{* * *} \\
(0.0174)\end{array}$ & $\begin{array}{c}0.1509 \text { *** } \\
(0.0190)\end{array}$ & $\begin{array}{c}0.1510^{* * *} \\
(0.0190)\end{array}$ \\
\hline Age group: $18-24$ & $\begin{array}{c}0.1448^{* *} \\
(0.0655)\end{array}$ & $\begin{array}{c}0.1649 * * \\
(0.0644)\end{array}$ & $\begin{array}{c}0.1630^{* *} \\
(0.0641)\end{array}$ & $\begin{array}{c}0.1451 * * \\
(0.0651)\end{array}$ & $\begin{array}{c}0.1418^{* *} \\
(0.0648)\end{array}$ \\
\hline Age group: $25-34$ & $\begin{array}{c}0.3200^{* * *} \\
(0.0716)\end{array}$ & $\begin{array}{c}0.3340^{* * *} \\
(0.0723)\end{array}$ & $\begin{array}{c}0.3323 * * * \\
(0.0722)\end{array}$ & $\begin{array}{c}0.3211^{* * *} \\
(0.0710)\end{array}$ & $\begin{array}{c}0.3180^{* * *} \\
(0.0710)\end{array}$ \\
\hline Age group: $35-44$ & $\begin{array}{c}0.4052^{* * *} \\
(0.0819)\end{array}$ & $\begin{array}{c}0.4171 * * * \\
(0.0826)\end{array}$ & $\begin{array}{c}0.4153 * * * \\
(0.0825)\end{array}$ & $\begin{array}{c}0.4067^{* * *} \\
(0.0813)\end{array}$ & $\begin{array}{c}0.4032^{* * *} \\
(0.0813)\end{array}$ \\
\hline Age group: 45-54 & $\begin{array}{c}0.4227^{* * *} \\
(0.0817)\end{array}$ & $\begin{array}{c}0.4340^{* * *} \\
(0.0824)\end{array}$ & $\begin{array}{c}0.4323 * * * \\
(0.0823)\end{array}$ & $\begin{array}{c}0.4239 * * * \\
(0.0810)\end{array}$ & $\begin{array}{c}0.4211^{* * *} \\
(0.0811)\end{array}$ \\
\hline Age group: $55+$ & $\begin{array}{c}0.4056^{* * *} \\
(0.0833)\end{array}$ & $\begin{array}{c}0.4127^{* * *} \\
(0.0854)\end{array}$ & $\begin{array}{c}0.4113 * * * \\
(0.0852)\end{array}$ & $\begin{array}{c}0.4060^{* * *} \\
(0.0828)\end{array}$ & $\begin{array}{c}0.4035^{* * *} \\
(0.0827)\end{array}$ \\
\hline Swahili & $\begin{array}{c}-0.1085^{* * *} \\
(0.0137)\end{array}$ & $\begin{array}{c}-0.1051 * * * \\
(0.0148)\end{array}$ & $\begin{array}{c}-0.1056^{* * *} \\
(0.0148)\end{array}$ & $\begin{array}{c}-0.1090^{* * *} \\
(0.0135)\end{array}$ & $\begin{array}{c}-0.1095^{* * *} \\
(0.0135)\end{array}$ \\
\hline Minority language & $\begin{array}{c}-0.1345 * * * \\
(0.0115)\end{array}$ & $\begin{array}{c}-0.1356^{* * *} \\
(0.0128)\end{array}$ & $\begin{array}{c}-0.1341^{* * *} \\
(0.0130)\end{array}$ & $\begin{array}{c}-0.1374^{* * *} \\
(0.0110)\end{array}$ & $\begin{array}{c}-0.1336^{* * *} \\
(0.0113)\end{array}$ \\
\hline Bank branches & $\begin{array}{c}0.0010^{* * *} \\
(0.0000)\end{array}$ & & & & \\
\hline Equity Bank presence & $\begin{array}{c}0.0424 * * * \\
(0.0108)\end{array}$ & & $\begin{array}{c}0.0233^{* *} \\
(0.0093)\end{array}$ & & $\begin{array}{c}0.0434 * * * \\
(0.0116)\end{array}$ \\
\hline Foreign bank presence & & $\begin{array}{c}0.0298^{*} \\
(0.0161)\end{array}$ & $\begin{array}{c}0.0278^{*} \\
(0.0162)\end{array}$ & & \\
\hline Gov. and gov.-influenced banks presence & & $\begin{array}{c}0.0381 * * * \\
(0.0127)\end{array}$ & $\begin{array}{c}0.0302^{* *} \\
(0.0136)\end{array}$ & & \\
\hline Domestic private banks presence & & $\begin{array}{c}0.0467^{* *} \\
(0.0183)\end{array}$ & $\begin{array}{c}0.0364 * * \\
(0.0185)\end{array}$ & & \\
\hline Foreign bank branches & & & & $\begin{array}{c}0.0115^{* * *} \\
(0.0032)\end{array}$ & $\begin{array}{c}0.0122^{* * *} \\
(0.0031)\end{array}$ \\
\hline Gov. and gov.-influenced bank branches & & & & $\begin{array}{c}0.0011 \\
(0.0037)\end{array}$ & $\begin{array}{l}-0.0020 \\
(0.0035)\end{array}$ \\
\hline Domestic private bank branches & & & & $\begin{array}{c}-0.0124 * * * \\
(0.0036)\end{array}$ & $\begin{array}{c}-0.0119 \text { *** } \\
(0.0036)\end{array}$ \\
\hline Observations & 10922 & 10922 & 10922 & 10922 & 10922 \\
\hline Pseudo R-squared & 0.332 & 0.327 & 0.327 & 0.332 & 0.333 \\
\hline District Fixed Effects & YES & YES & YES & YES & YES \\
\hline
\end{tabular}




\section{Table 6}

\section{Instrumental Variables}

This table reports estimates from IV GMM and IV Probit models of the probability of having a bank account against the variables listed below. The data consists of 4,360 individual interviewed in 2006 and 6,562 individual in 2009. Equity Bank presence is instrumented with the district-level proportion of people speaking a minority language and its interaction with a 2009 dummy variable. Robust standard errors are in parentheses. Standard errors are clustered by district-year groups. ***, $* *, *$ indicate significance at the $1 \%, 5 \%$ and $10 \%$ levels, respectively.

\begin{tabular}{|c|c|c|c|c|c|}
\hline \multirow[b]{2}{*}{ Dep. variable: Bank account } & \multicolumn{2}{|c|}{ IV GMM } & \multicolumn{3}{|c|}{ IV Probit } \\
\hline & $\begin{array}{c}\text { Second stage } \\
(1)\end{array}$ & $\begin{array}{c}\text { First stage } \\
(2)\end{array}$ & $\begin{array}{c}\text { Marginal effects } \\
\text { Second stage } \\
\text { (3) }\end{array}$ & $\begin{array}{c}\text { Second stage } \\
\text { (4) }\end{array}$ & $\begin{array}{c}\text { First stage } \\
(5)\end{array}$ \\
\hline Household size & $\begin{array}{c}-0.0081^{* * *} \\
(0.0014)\end{array}$ & $\begin{array}{c}0.0089 * * * \\
(0.0009)\end{array}$ & $\begin{array}{c}-0.0068^{* * *} \\
(0.0015)\end{array}$ & $\begin{array}{c}-0.0359 \text { *** } \\
(0.0078)\end{array}$ & $\begin{array}{c}0.0089 * * * \\
(0.0009)\end{array}$ \\
\hline Education: Primary & $\begin{array}{c}-0.0239 * * * \\
(0.0080)\end{array}$ & $\begin{array}{c}-0.0112^{*} \\
(0.0061)\end{array}$ & $\begin{array}{c}0.0068 \\
(0.0100)\end{array}$ & $\begin{array}{c}0.0352 \\
(0.0512)\end{array}$ & $\begin{array}{c}-0.0112 * \\
(0.0061)\end{array}$ \\
\hline Education: Secondary & $\begin{array}{c}0.1019 * * * \\
(0.0120)\end{array}$ & $\begin{array}{c}-0.0247^{* * *} \\
(0.0069)\end{array}$ & $\begin{array}{c}0.1284^{* * *} \\
(0.0139)\end{array}$ & $\begin{array}{c}0.5465^{* * *} \\
(0.0502)\end{array}$ & $\begin{array}{c}-0.0247^{* * *} \\
(0.0069)\end{array}$ \\
\hline Education: Tertiary & $\begin{array}{c}0.2298^{* * *} \\
(0.0320)\end{array}$ & $\begin{array}{l}-0.0254^{*} \\
(0.0152)\end{array}$ & $\begin{array}{c}0.3051 \text { *** } \\
(0.0622)\end{array}$ & $\begin{array}{c}1.0115^{* * *} \\
(0.1601)\end{array}$ & $\begin{array}{c}-0.0253^{*} \\
(0.0151)\end{array}$ \\
\hline Female & $\begin{array}{c}-0.0473 * * * \\
(0.0065)\end{array}$ & $\begin{array}{c}-0.0158^{* * *} \\
(0.0048)\end{array}$ & $\begin{array}{c}-0.0558^{* * *} \\
(0.0070)\end{array}$ & $\begin{array}{c}-0.2938^{* * *} \\
(0.0380)\end{array}$ & $\begin{array}{c}-0.0158^{* * *} \\
(0.0048)\end{array}$ \\
\hline Asset score & $\begin{array}{c}0.0386 * * * \\
(0.0021)\end{array}$ & $\begin{array}{c}-0.0013^{*} \\
(0.0008)\end{array}$ & $\begin{array}{c}0.0281 * * * \\
(0.0019)\end{array}$ & $\begin{array}{c}0.1469^{* * *} \\
(0.0095)\end{array}$ & $\begin{array}{c}-0.0013^{*} \\
(0.0008)\end{array}$ \\
\hline Own permanent house & $\begin{array}{c}0.0573^{* * *} \\
(0.0106)\end{array}$ & $\begin{array}{c}-0.0181^{* * *} \\
(0.0059)\end{array}$ & $\begin{array}{c}0.0534^{* * *} \\
(0.0106)\end{array}$ & $\begin{array}{c}0.2527 * * * \\
(0.0458)\end{array}$ & $\begin{array}{c}-0.0181 * * * \\
(0.0059)\end{array}$ \\
\hline Income type: Agriculture & $\begin{array}{c}0.0314 * * * \\
(0.0091)\end{array}$ & $\begin{array}{l}-0.0107 \\
(0.0076)\end{array}$ & $\begin{array}{c}0.0333^{* *} \\
(0.0144)\end{array}$ & $\begin{array}{c}0.1712^{* *} \\
(0.0729)\end{array}$ & $\begin{array}{l}-0.0107 \\
(0.0075)\end{array}$ \\
\hline Income type: Waged & $\begin{array}{c}0.1847 * * * \\
(0.0132)\end{array}$ & $\begin{array}{c}-0.0218^{* * *} \\
(0.0082)\end{array}$ & $\begin{array}{c}0.2200^{* * *} \\
(0.0234)\end{array}$ & $\begin{array}{c}0.8487 * * * \\
(0.0736)\end{array}$ & $\begin{array}{c}-0.0218^{* * *} \\
(0.0082)\end{array}$ \\
\hline Income type: Business & $\begin{array}{c}0.1268^{* * *} \\
(0.0104)\end{array}$ & $\begin{array}{l}-0.0048 \\
(0.0075)\end{array}$ & $\begin{array}{c}0.1523^{* * *} \\
(0.0180)\end{array}$ & $\begin{array}{c}0.6734 * * * \\
(0.0697)\end{array}$ & $\begin{array}{l}-0.0047 \\
(0.0074)\end{array}$ \\
\hline Age group: 18-24 & $\begin{array}{l}-0.0038 \\
(0.0120)\end{array}$ & $\begin{array}{c}0.0339 * * * \\
(0.0119)\end{array}$ & $\begin{array}{c}0.1389^{* *} \\
(0.0541)\end{array}$ & $\begin{array}{c}0.5900^{* * *} \\
(0.1963)\end{array}$ & $\begin{array}{c}0.0339 \text { *** } \\
(0.0119)\end{array}$ \\
\hline Age group: $25-34$ & $\begin{array}{c}0.1022^{* * *} \\
(0.0123)\end{array}$ & $\begin{array}{c}0.0335^{* * *} \\
(0.0120)\end{array}$ & $\begin{array}{c}0.3134^{* * *} \\
(0.0591)\end{array}$ & $\begin{array}{c}1.2218^{* * *} \\
(0.1955)\end{array}$ & $\begin{array}{c}0.0335^{* * *} \\
(0.0119)\end{array}$ \\
\hline Age group: $35-44$ & $\begin{array}{c}0.1349 * * * \\
(0.0129)\end{array}$ & $\begin{array}{c}0.0266^{* *} \\
(0.0122)\end{array}$ & $\begin{array}{c}0.3986 \text { *** } \\
(0.0657)\end{array}$ & $\begin{array}{c}1.4130^{* * *} \\
(0.1965)\end{array}$ & $\begin{array}{c}0.0266^{* *} \\
(0.0122)\end{array}$ \\
\hline Age group: $45-54$ & $\begin{array}{c}0.1273^{* * *} \\
(0.0142)\end{array}$ & $\begin{array}{c}0.0271 * * \\
(0.0129)\end{array}$ & $\begin{array}{c}0.4167 \text { *** } \\
(0.0714)\end{array}$ & $\begin{array}{c}1.3884 * * * \\
(0.1987)\end{array}$ & $\begin{array}{c}0.0271^{* *} \\
(0.0129)\end{array}$ \\
\hline Age group: $55+$ & $\begin{array}{c}0.1125^{* * *} \\
(0.0135)\end{array}$ & $\begin{array}{c}0.0254^{* *} \\
(0.0129)\end{array}$ & $\begin{array}{c}0.3990^{* * *} \\
(0.0693)\end{array}$ & $\begin{array}{c}1.3768^{* * *} \\
(0.1998)\end{array}$ & $\begin{array}{c}0.0254^{* *} \\
(0.0129)\end{array}$ \\
\hline Swahili & $\begin{array}{c}-0.1737^{* * *} * \\
(0.0159)\end{array}$ & $\begin{array}{l}-0.0058 \\
(0.0067)\end{array}$ & $\begin{array}{c}-0.1095^{* * *} \\
(0.0119)\end{array}$ & $\begin{array}{c}-0.5412^{* * *} \\
(0.0550)\end{array}$ & $\begin{array}{l}-0.0058 \\
(0.0067)\end{array}$ \\
\hline Minority language & $\begin{array}{c}-0.2130^{* * *} \\
(0.0170)\end{array}$ & $\begin{array}{l}-0.0102 \\
(0.0085)\end{array}$ & $\begin{array}{c}-0.1280^{* * *} * \\
(0.0094)\end{array}$ & $\begin{array}{c}-0.7956 \text { *** } \\
(0.0676)\end{array}$ & $\begin{array}{l}-0.0103 \\
(0.0085)\end{array}$ \\
\hline Bank branches & $\begin{array}{c}0.0012 * * * \\
(0.0002)\end{array}$ & $\begin{array}{c}-0.0000^{* * *} \\
(0.0000)\end{array}$ & $\begin{array}{c}0.0010^{* * *} \\
(0.0001)\end{array}$ & $\begin{array}{c}0.0052^{* * *} \\
(0.0007)\end{array}$ & $\begin{array}{c}-0.0000^{* * *} \\
(0.0000)\end{array}$ \\
\hline Equity Bank presence & $\begin{array}{c}0.0939 * * * \\
(0.0197)\end{array}$ & & $\begin{array}{c}0.0984 * * * \\
(0.0187)\end{array}$ & $\begin{array}{c}0.5989 * * * \\
(0.1307)\end{array}$ & \\
\hline Minority language district & & $\begin{array}{c}-0.9086^{* * *} \\
(0.0224)\end{array}$ & & & $\begin{array}{c}-0.9069^{* * *} \\
(0.0223)\end{array}$ \\
\hline Minority language district x Dummy(2009) & & $\begin{array}{c}0.2313^{* * *} \\
(0.0187)\end{array}$ & & & $\begin{array}{c}0.2333^{* * *} \\
(0.0186)\end{array}$ \\
\hline Observations & 10922 & 10923 & 10922 & 10922 & 10922 \\
\hline Centered R-squared & 0.7585 & & & & \\
\hline Uncentered R-squared & 0.9311 & & & & \\
\hline Probability of positive outcome (predict, p) & & & 0.1128 & & \\
\hline Partial R-squared of excluded instruments: & & 0.2822 & & & \\
\hline p-value of test of excluded instruments & & 0.0000 & & & \\
\hline p-value of Hansen J statistic & 0.1924 & & & & \\
\hline District Fixed Effects & YES & YES & YES & YES & YES \\
\hline
\end{tabular}




\section{Table 7 \\ Interaction Effects}

This table reports estimates from a Probit model of the probability of having a bank account against the variables listed below. The data consists of 4,360 individual interviewed in 2006 and 6,562 individual in 2009. Robust standard errors are in parentheses. Standard errors are clustered by district-year groups. ${ }^{* * *}, * *, *$ indicate significance at the $1 \%, 5 \%$ and $10 \%$ levels, respectively.

Dep. variable: Bank account

$(1) \quad(2)$

$(3)$

(4)

(5)

Equity Bank presence

$\begin{array}{ccccc}0.0708^{* * *} & 0.0528^{* * *} & 0.0578^{* * *} & 0.0521 * * * & 0.0911^{* * *} \\ (0.0157) & (0.0115) & (0.0114) & (0.0115) & (0.0167) \\ -0.0153^{* *} & & & & -0.0119^{*} \\ (0.0066) & & & & (0.0067) \\ & -0.0506^{* * *} & & -0.0431^{* *} \\ & (0.0191) & & (0.0193) \\ & & -0.0515^{* * *} & -0.0414^{* *} \\ & & (0.0156) & & (0.0163) \\ & & & -0.0416^{* *} & -0.0372^{* *} \\ & & & (0.0168) & (0.0175)\end{array}$

Asset score x Equity Bank presence

Permanent own house x Equity Bank presence

Secondary-Tertiary Education x Equity Bank presence

Salaried job x Equity Bank presence

$(0.0168) \quad(0.0175)$

\begin{tabular}{lccccc}
\hline Observations & 10922 & 10922 & 10922 & 10922 & 10922 \\
Pseudo R-squared & 0.333 & 0.333 & 0.333 & 0.333 & 0.335 \\
\hline Control Variables & YES & YES & YES & YES & YES \\
District Fixed Effects & YES & YES & YES & YES & YES \\
\hline \hline
\end{tabular}




\section{Table 8 \\ Access to Credit}

This table reports estimates from a ordered Probit model of the probability of access to bank services against the variables listed below. Bank services take the value 0 if the individual has neither a bank account nor a bank loan; it takes the value 1 if the individual has a bank account; it takes the value 2 if the individual has a bank loan. The data consists of 4,360 individual interviewed in 2006 and 6,562 individual in 2009. Robust standard errors are in parentheses. ***, **, $*$ indicate significance at the $1 \%, 5 \%$ and $10 \%$ levels, respectively.

\begin{tabular}{|c|c|c|c|c|}
\hline & \multirow{3}{*}{$\begin{array}{c}\text { (1) } \\
\text { Ordered Probit }\end{array}$} & \multirow{2}{*}{\multicolumn{3}{|c|}{$\begin{array}{c}\text { (3) } \\
\text { Average Marginal Effects }\end{array}$}} \\
\hline & & & & \\
\hline & & $\begin{array}{r}\text { Financial } \\
\text { Acces }=0\end{array}$ & $\begin{array}{r}\text { Financial } \\
\text { Acces }=1 \\
\end{array}$ & $\begin{array}{r}\text { Financial } \\
\text { Acces }=2 \\
\end{array}$ \\
\hline Household size & $\begin{array}{c}-0.0236 * * * \\
(0.0075)\end{array}$ & $\begin{array}{c}0.0044 * * * \\
(0.0014)\end{array}$ & $\begin{array}{c}-0.0032^{* * * *} \\
(0.0010)\end{array}$ & $\begin{array}{c}-0.0012^{* * *} \\
(0.0003)\end{array}$ \\
\hline Education: Primary & $\begin{array}{c}0.0102 \\
(0.0481)\end{array}$ & $\begin{array}{l}-0.0019 \\
(0.0090)\end{array}$ & $\begin{array}{c}0.0013 \\
(0.0065)\end{array}$ & $\begin{array}{c}0.0005 \\
(0.0024)\end{array}$ \\
\hline Education: Secondary & $\begin{array}{c}0.4613^{* * *} \\
(0.0453)\end{array}$ & $\begin{array}{c}-0.0867 * * * \\
(0.0084)\end{array}$ & $\begin{array}{c}0.0631 * * * \\
(0.0061)\end{array}$ & $\begin{array}{c}0.0236 * * * \\
(0.0024)\end{array}$ \\
\hline Education: Tertiary & $\begin{array}{c}0.8370^{* * *} \\
(0.1105)\end{array}$ & $\begin{array}{l}-0.1574 * * * \\
(0.0207)\end{array}$ & $\begin{array}{c}0.1145^{* * *} \\
(0.0153)\end{array}$ & $\begin{array}{c}0.0428^{* * *} \\
(0.0057)\end{array}$ \\
\hline Female & $\begin{array}{c}-0.2897 * * * \\
(0.0352)\end{array}$ & $\begin{array}{c}0.0544 * * * \\
(0.0065)\end{array}$ & $\begin{array}{c}-0.0396 * * * \\
(0.0048)\end{array}$ & $\begin{array}{c}-0.0148 * * * \\
(0.0018)\end{array}$ \\
\hline Asset score & $\begin{array}{c}0.1339 * * * \\
(0.0075)\end{array}$ & $\begin{array}{c}-0.0251 * * * \\
(0.0013)\end{array}$ & $\begin{array}{c}0.0183^{* * *} \\
(0.0010)\end{array}$ & $\begin{array}{c}0.0068^{* * *} \\
(0.0004)\end{array}$ \\
\hline Own permanent house & $\begin{array}{c}0.2188^{* * *} \\
(0.0416)\end{array}$ & $\begin{array}{c}-0.0411 * * * \\
(0.0078)\end{array}$ & $\begin{array}{c}0.0299 * * * \\
(0.0057)\end{array}$ & $\begin{array}{c}0.0112^{* * *} \\
(0.0021)\end{array}$ \\
\hline Income type: Agriculture & $\begin{array}{c}0.1406^{* *} \\
(0.0672)\end{array}$ & $\begin{array}{c}-0.0264 * * \\
(0.0126)\end{array}$ & $\begin{array}{c}0.0192 * * * \\
(0.0092)\end{array}$ & $\begin{array}{c}0.0072^{* * *} \\
(0.0034)\end{array}$ \\
\hline Income type: Waged & $\begin{array}{c}0.8507 * * * \\
(0.0667)\end{array}$ & $\begin{array}{c}-0.1600^{* * *} \\
(0.0123)\end{array}$ & $\begin{array}{c}0.1164 * * * \\
(0.0089)\end{array}$ & $\begin{array}{c}0.0435^{* * *} \\
(0.0037)\end{array}$ \\
\hline Income type: Business & $\begin{array}{l}0.643 * * * \\
(0.0636)\end{array}$ & $\begin{array}{c}-0.1209 * * * \\
(0.0118)\end{array}$ & $\begin{array}{l}0.0880^{* * *} \\
(0.0086)\end{array}$ & $\begin{array}{c}0.0329 * * * \\
(0.0034)\end{array}$ \\
\hline Age group: 18-24 & $\begin{array}{c}0.5530^{* * *} \\
(0.1766)\end{array}$ & $\begin{array}{c}-0.104 * * * \\
(0.0332)\end{array}$ & $\begin{array}{l}0.0756^{* * *} \\
(0.0241)\end{array}$ & $\begin{array}{c}0.0283^{* * *} \\
(0.0091)\end{array}$ \\
\hline Age group: 25-34 & $\begin{array}{l}1.1742^{* * *} \\
(0.1749)\end{array}$ & $\begin{array}{c}-0.2208^{* * *} \\
(0.0327)\end{array}$ & $\begin{array}{c}0.1606^{* * *} \\
(0.0239)\end{array}$ & $\begin{array}{c}0.0601 * * * \\
(0.0092)\end{array}$ \\
\hline Age group: $35-44$ & $\begin{array}{c}1.3964 * * * \\
(0.1756)\end{array}$ & $\begin{array}{c}-0.2626^{* * *} \\
(0.0328)\end{array}$ & $\begin{array}{c}0.1911 * * * \\
(0.0239)\end{array}$ & $\begin{array}{c}0.0715^{* * *} \\
(0.0093)\end{array}$ \\
\hline Age group: 45-54 & $\begin{array}{l}1.3846^{* * *} \\
(0.1778)\end{array}$ & $\begin{array}{c}-0.2604 * * * \\
(0.0332)\end{array}$ & $\begin{array}{l}0.1895^{* * *} \\
(0.0242)\end{array}$ & $\begin{array}{c}0.0709 * * * \\
(0.0094)\end{array}$ \\
\hline Age group: 55+ & $\begin{array}{c}1.3174 * * * \\
(0.1786)\end{array}$ & $\begin{array}{c}-0.2477 * * * \\
(0.0334)\end{array}$ & $\begin{array}{c}0.1803 * * * \\
(0.0244)\end{array}$ & $\begin{array}{c}0.0674^{* * *} \\
(0.0094)\end{array}$ \\
\hline Swahili & $\begin{array}{c}-0.5212^{* * * *} \\
(0.0489)\end{array}$ & $\begin{array}{c}0.0980^{* * *} \\
(0.0091)\end{array}$ & $\begin{array}{c}-0.0713 * * * \\
(0.0066)\end{array}$ & $\begin{array}{c}-0.0267 * * * \\
(0.0026)\end{array}$ \\
\hline Minority language & $\begin{array}{c}-0.8039 * * * \\
(0.0610)\end{array}$ & $\begin{array}{c}0.1512 * * * \\
(0.0113)\end{array}$ & $\begin{array}{c}-0.1100^{* * *} \\
(0.0083)\end{array}$ & $\begin{array}{c}-0.0411 \text { *** } \\
(0.0034)\end{array}$ \\
\hline Bank branches & $\begin{array}{c}0.0039 * * * \\
(0.0006)\end{array}$ & $\begin{array}{c}-0.0007 * * * \\
(0.0001)\end{array}$ & $\begin{array}{c}0.0005^{* * *} \\
(0.0000)\end{array}$ & $\begin{array}{c}0.0002^{* * *} \\
(0.0000)\end{array}$ \\
\hline Equity Bank presence & $\begin{array}{c}0.2637 * * * \\
(0.0683)\end{array}$ & $\begin{array}{c}-0.0496^{* * *} \\
(0.0128)\end{array}$ & $\begin{array}{c}0.0360 * * * \\
(0.0093)\end{array}$ & $\begin{array}{c}0.0135^{* * *} \\
(0.0035)\end{array}$ \\
\hline Observations & 10922 & 10922 & 10922 & 10922 \\
\hline Pseudo R-squared & 0.2918 & & & \\
\hline District Fixed Effects & YES & YES & YES & YES \\
\hline
\end{tabular}




\section{Table 9}

\section{Rural and Arid and Semi-Arid Districts}

This table reports estimates from a Probit model of the probability of having a bank account against the variables listed below. Robust standard errors are in parentheses. Standard errors are clustered by district-year groups. ***, **, * indicate significance at the $1 \%, 5 \%$ and $10 \%$ levels, respectively.

\begin{tabular}{|c|c|c|c|c|c|}
\hline Dep. variable: Bank account & $(1)$ & $(2)$ & (3) & $(4)$ & $(5)$ \\
\hline Household size & $\begin{array}{c}-0.0039 * * * \\
(0.0013)\end{array}$ & $\begin{array}{c}-0.0037^{* * *} \\
(0.0013)\end{array}$ & $\begin{array}{c}-0.0038^{* * *} \\
(0.0013)\end{array}$ & $\begin{array}{c}-0.0036^{* * *} \\
(0.0014)\end{array}$ & $\begin{array}{c}-0.0039 * * * \\
(0.0013)\end{array}$ \\
\hline Education: Primary & $\begin{array}{c}0.0125 \\
(0.0087)\end{array}$ & $\begin{array}{c}0.0070 \\
(0.0081)\end{array}$ & $\begin{array}{c}0.0086 \\
(0.0083)\end{array}$ & $\begin{array}{c}0.0123 \\
(0.0085)\end{array}$ & $\begin{array}{l}0.0144^{*} \\
(0.0086)\end{array}$ \\
\hline Education: Secondary & $\begin{array}{c}0.1110^{* * *} \\
(0.0150)\end{array}$ & $\begin{array}{c}0.1009 \text { *** } \\
(0.0133)\end{array}$ & $\begin{array}{c}0.1038^{* * *} \\
(0.0138)\end{array}$ & $\begin{array}{c}0.1101^{* * *} \\
(0.0152)\end{array}$ & $\begin{array}{c}0.1138^{* * *} \\
(0.0155)\end{array}$ \\
\hline Education: Tertiary & $\begin{array}{c}0.2862^{* * *} \\
(0.0967)\end{array}$ & $\begin{array}{c}0.2714^{* * *} \\
(0.0944)\end{array}$ & $\begin{array}{c}0.2788^{* * *} \\
(0.0955)\end{array}$ & $\begin{array}{c}0.2710^{* * *} \\
(0.0961)\end{array}$ & $\begin{array}{c}0.2846^{* * *} \\
(0.0989)\end{array}$ \\
\hline Female & $\begin{array}{c}-0.0432^{* * *} \\
(0.0067)\end{array}$ & $\begin{array}{c}-0.0428^{* * *} \\
(0.0065)\end{array}$ & $\begin{array}{c}-0.0428^{* * *} \\
(0.0065)\end{array}$ & $\begin{array}{c}-0.0430 * * * \\
(0.0067)\end{array}$ & $\begin{array}{c}-0.0427 * * * \\
(0.0066)\end{array}$ \\
\hline Asset score & $\begin{array}{c}0.0314^{* * *} \\
(0.0026)\end{array}$ & $\begin{array}{c}0.0320^{* * *} \\
(0.0026)\end{array}$ & $\begin{array}{c}0.0318^{* * *} \\
(0.0026)\end{array}$ & $\begin{array}{c}0.0314 * * * \\
(0.0026)\end{array}$ & $\begin{array}{c}0.0312^{* * *} \\
(0.0026)\end{array}$ \\
\hline Own permanent house & $\begin{array}{c}0.0493 * * * \\
(0.0135)\end{array}$ & $\begin{array}{c}0.0496 * * * \\
(0.0133)\end{array}$ & $\begin{array}{c}0.0495^{* * *} \\
(0.0133)\end{array}$ & $\begin{array}{c}0.0482 \text { *** } \\
(0.0136)\end{array}$ & $\begin{array}{c}0.0477^{* * *} \\
(0.0135)\end{array}$ \\
\hline Income type: Agriculture & $\begin{array}{c}0.0217 \\
(0.0136)\end{array}$ & $\begin{array}{c}0.0201 \\
(0.0136)\end{array}$ & $\begin{array}{c}0.0205 \\
(0.0136)\end{array}$ & $\begin{array}{c}0.0209 \\
(0.0136)\end{array}$ & $\begin{array}{c}0.0213 \\
(0.0136)\end{array}$ \\
\hline Income type: Waged & $\begin{array}{c}0.1868^{* * *} \\
(0.0303)\end{array}$ & $\begin{array}{c}0.1818^{* * *} \\
(0.0297)\end{array}$ & $\begin{array}{c}0.1838^{* * *} \\
(0.0300)\end{array}$ & $\begin{array}{c}0.1854 * * * \\
(0.0301)\end{array}$ & $\begin{array}{c}0.1873^{* * *} \\
(0.0303)\end{array}$ \\
\hline Income type: Business & $\begin{array}{c}0.1018^{* * *} \\
(0.0196)\end{array}$ & $\begin{array}{c}0.0998^{* * *} \\
(0.0194)\end{array}$ & $\begin{array}{c}0.0999 * * * \\
(0.0194)\end{array}$ & $\begin{array}{c}0.1017^{* * *} \\
(0.0196)\end{array}$ & $\begin{array}{c}0.1016 \text { *** } \\
(0.0196)\end{array}$ \\
\hline Age group: $18-24$ & $\begin{array}{c}0.1971 * * \\
(0.0877)\end{array}$ & $\begin{array}{c}0.2072^{* *} \\
(0.0902)\end{array}$ & $\begin{array}{c}0.2027^{* *} \\
(0.0894)\end{array}$ & $\begin{array}{c}0.1974 * * \\
(0.0867)\end{array}$ & $\begin{array}{c}0.1920^{* *} \\
(0.0858)\end{array}$ \\
\hline Age group: $25-34$ & $\begin{array}{c}0.3732^{* * *} \\
(0.1020)\end{array}$ & $\begin{array}{c}0.3822^{* * *} \\
(0.1036)\end{array}$ & $\begin{array}{c}0.3780^{* * *} \\
(0.1034)\end{array}$ & $\begin{array}{c}0.3749 \text { *** } \\
(0.1009)\end{array}$ & $\begin{array}{c}0.3696^{* * *} \\
(0.1006)\end{array}$ \\
\hline Age group: $35-44$ & $\begin{array}{c}0.4738^{* * *} \\
(0.1079)\end{array}$ & $\begin{array}{c}0.4821 * * * \\
(0.1094)\end{array}$ & $\begin{array}{c}0.4776^{* * *} \\
(0.1093)\end{array}$ & $\begin{array}{c}0.4760 \text { *** } \\
(0.1068)\end{array}$ & $\begin{array}{c}0.4702^{* * *} \\
(0.1067)\end{array}$ \\
\hline Age group: $45-54$ & $\begin{array}{c}0.5018^{* * *} \\
(0.1148)\end{array}$ & $\begin{array}{c}0.5098^{* * *} \\
(0.1158)\end{array}$ & $\begin{array}{c}0.5054^{* * *} \\
(0.1159)\end{array}$ & $\begin{array}{c}0.5036 \text { *** } \\
(0.1136)\end{array}$ & $\begin{array}{c}0.4983^{* * *} \\
(0.1137)\end{array}$ \\
\hline Age group: $55+$ & $\begin{array}{c}0.4874^{* * *} \\
(0.1098)\end{array}$ & $\begin{array}{c}0.4949^{* * *} \\
(0.1111)\end{array}$ & $\begin{array}{c}0.4912^{* * *} \\
(0.1111)\end{array}$ & $\begin{array}{c}0.4882^{* * *} \\
(0.1088)\end{array}$ & $\begin{array}{c}0.4835^{\text {*** }} \\
(0.1087)\end{array}$ \\
\hline Swahili & $\begin{array}{c}-0.0795^{* * *} \\
(0.0143)\end{array}$ & $\begin{array}{c}-0.0764 * * * \\
(0.0144)\end{array}$ & $\begin{array}{c}-0.0771 \text { *** } \\
(0.0145)\end{array}$ & $\begin{array}{c}-0.0805^{* * *} \\
(0.0142)\end{array}$ & $\begin{array}{c}-0.0807 * * * \\
(0.0143)\end{array}$ \\
\hline Minority language & $\begin{array}{c}-0.0981^{* * *} \\
(0.0110)\end{array}$ & $\begin{array}{c}-0.1009^{* * *} \\
(0.0110)\end{array}$ & $\begin{array}{c}-0.0995^{* * *} \\
(0.0111)\end{array}$ & $\begin{array}{c}-0.0997^{* * *} \\
(0.0106)\end{array}$ & $\begin{array}{c}-0.0974 * * * \\
(0.0108)\end{array}$ \\
\hline Bank branches & $\begin{array}{c}0.0042 * * * \\
(0.0014)\end{array}$ & & & & \\
\hline Equity Bank presence & $\begin{array}{c}0.0247^{* * *} \\
(0.0091)\end{array}$ & & $\begin{array}{c}0.0207 * * * \\
(0.0072)\end{array}$ & & $\begin{array}{c}0.0277^{* * *} \\
(0.0102)\end{array}$ \\
\hline Foreign bank presence & & $\begin{array}{c}0.0200 \\
(0.0130)\end{array}$ & $\begin{array}{c}0.0184 \\
(0.0131)\end{array}$ & & \\
\hline Gov. and gov.-influenced bank presence & & $\begin{array}{c}0.0289 * * * \\
(0.0096)\end{array}$ & $\begin{array}{c}0.0221 * * \\
(0.0103)\end{array}$ & & \\
\hline Domestic private bank presence & & $\begin{array}{c}0.0369 * * \\
(0.0144)\end{array}$ & $\begin{array}{c}0.0278^{*} \\
(0.0144)\end{array}$ & & \\
\hline Foreign bank branches & & & & $\begin{array}{c}0.0132^{* * *} \\
(0.0028)\end{array}$ & $\begin{array}{c}0.0132 * * * \\
(0.0026)\end{array}$ \\
\hline Gov. and gov.-influenced bank branches & & & & $\begin{array}{c}0.0025 \\
(0.0024)\end{array}$ & $\begin{array}{l}-0.0004 \\
(0.0029)\end{array}$ \\
\hline Domestic private bank branches & & & & $\begin{array}{l}-0.0046 \\
(0.0039)\end{array}$ & $\begin{array}{l}-0.0043 \\
(0.0041)\end{array}$ \\
\hline Observations & 9388 & 9388 & 9388 & 9388 & 9388 \\
\hline Pseudo R-squared & 0.316 & 0.315 & 0.316 & 0.317 & 0.317 \\
\hline District Fixed Effects & YES & YES & YES & YES & YES \\
\hline
\end{tabular}




\section{Table 10}

\section{Difference-in-Differences Estimator}

This table reports estimates from a Probit model of the probability of having a bank account against the variables listed below. Only the districts without Equity Bank presence in 2006 and with and without Equity Bank presence in 2009 are considered. Robust standard errors are in parentheses. Standard errors are clustered by district-year groups. ${ }^{* *}$, **, $*$ indicate significance at the $1 \%, 5 \%$ and $10 \%$ levels, respectively.

\begin{tabular}{|c|c|c|c|}
\hline Dep. variable: Bank account & $(1)$ & $(2)$ & (3) \\
\hline Household size & $\begin{array}{c}-0.0023 * * \\
(0.0010)\end{array}$ & $\begin{array}{c}-0.0022^{* *} \\
(0.0010)\end{array}$ & $\begin{array}{c}-0.0023^{* *} \\
(0.0010)\end{array}$ \\
\hline Education: Primary & $\begin{array}{c}0.0171^{*} \\
(0.0100)\end{array}$ & $\begin{array}{c}0.0173^{*} \\
(0.0100)\end{array}$ & $\begin{array}{c}0.0171^{*} \\
(0.0100)\end{array}$ \\
\hline Education: Secondary & $\begin{array}{c}0.1099 * * * \\
(0.0174)\end{array}$ & $\begin{array}{c}0.1102^{* * *} \\
(0.0175)\end{array}$ & $\begin{array}{c}0.1100^{* * *} \\
(0.0174)\end{array}$ \\
\hline Education: Tertiary & $\begin{array}{c}0.1792^{* *} \\
(0.0767)\end{array}$ & $\begin{array}{c}0.1795^{* *} \\
(0.0766)\end{array}$ & $\begin{array}{c}0.1773^{* *} \\
(0.0769)\end{array}$ \\
\hline Female & $\begin{array}{c}-0.0279^{* * * *} \\
(0.0062)\end{array}$ & $\begin{array}{c}-0.0276^{* * * *} \\
(0.0061)\end{array}$ & $\begin{array}{c}-0.0280^{* * *} \\
(0.0061)\end{array}$ \\
\hline Asset score & $\begin{array}{c}0.0259 * * * \\
(0.0021)\end{array}$ & $\begin{array}{c}0.0259 * * * \\
(0.0021)\end{array}$ & $\begin{array}{c}0.0259 * * * \\
(0.0021)\end{array}$ \\
\hline Own permanent house & $\begin{array}{c}0.0423^{* * *} \\
(0.0097)\end{array}$ & $\begin{array}{c}0.0417^{* * *} \\
(0.0096)\end{array}$ & $\begin{array}{c}0.0425 * * * \\
(0.0098)\end{array}$ \\
\hline Income type: Agriculture & $\begin{array}{c}0.0047 \\
(0.0134)\end{array}$ & $\begin{array}{c}0.0051 \\
(0.0134)\end{array}$ & $\begin{array}{c}0.0045 \\
(0.0133)\end{array}$ \\
\hline Income type: Waged & $\begin{array}{c}0.1502^{* * *} \\
(0.0353)\end{array}$ & $\begin{array}{c}0.1501 * * * \\
(0.0357)\end{array}$ & $\begin{array}{c}0.1503^{* * *} \\
(0.0354)\end{array}$ \\
\hline Income type: Business & $\begin{array}{c}0.0560^{* * *} \\
(0.0187)\end{array}$ & $\begin{array}{c}0.0563^{* * *} \\
(0.0188)\end{array}$ & $\begin{array}{c}0.0558^{* * *} \\
(0.0187)\end{array}$ \\
\hline Age group: $18-24$ & $\begin{array}{c}0.1029 \\
(0.0661)\end{array}$ & $\begin{array}{c}0.1051 \\
(0.0669)\end{array}$ & $\begin{array}{c}0.1035 \\
(0.0661)\end{array}$ \\
\hline Age group: 25-34 & $\begin{array}{c}0.1878^{* *} \\
(0.0844)\end{array}$ & $\begin{array}{c}0.1889 * * \\
(0.0849)\end{array}$ & $\begin{array}{c}0.1884^{* *} \\
(0.0843)\end{array}$ \\
\hline Age group: $35-44$ & $\begin{array}{c}0.2794^{* * *} \\
(0.1019)\end{array}$ & $\begin{array}{c}0.2807^{* * *} \\
(0.1025)\end{array}$ & $\begin{array}{c}0.2800^{* * *} \\
(0.1017)\end{array}$ \\
\hline Age group: $45-54$ & $\begin{array}{c}0.2993 * * * \\
(0.1141)\end{array}$ & $\begin{array}{c}0.3020 * * * \\
(0.1147)\end{array}$ & $\begin{array}{c}0.2999 * * * \\
(0.1137)\end{array}$ \\
\hline Age group: $55+$ & $\begin{array}{c}0.3178^{* * *} \\
(0.1100)\end{array}$ & $\begin{array}{c}0.3203^{* * *} \\
(0.1104)\end{array}$ & $\begin{array}{c}0.3187 * * * \\
(0.1097)\end{array}$ \\
\hline Swahili & $\begin{array}{c}-0.0519^{* * *} \\
(0.0125)\end{array}$ & $\begin{array}{c}-0.0507^{* * *} \\
(0.0125)\end{array}$ & $\begin{array}{c}-0.0522 * * * \\
(0.0125)\end{array}$ \\
\hline Minority language & $\begin{array}{c}-0.0652^{* * * *} \\
(0.0093)\end{array}$ & $\begin{array}{c}-0.0648^{* * * *} \\
(0.0093)\end{array}$ & $\begin{array}{c}-0.0652 * * * \\
(0.0093)\end{array}$ \\
\hline Bank branches & $\begin{array}{l}-0.0021 \\
(0.0019)\end{array}$ & & \\
\hline Equity Bank presence & $\begin{array}{c}0.0293 * * \\
(0.0118)\end{array}$ & $\begin{array}{c}0.0198^{* *} \\
(0.0092)\end{array}$ & $\begin{array}{c}0.0280 * * \\
(0.0119)\end{array}$ \\
\hline Foreign bank presence & & $\begin{array}{c}0.0038 \\
(0.0109)\end{array}$ & \\
\hline Gov. and gov.-influenced banks presence & & $\begin{array}{c}0.0181^{* *} \\
(0.0079)\end{array}$ & \\
\hline Domestic Private banks presence & & $\begin{array}{l}0.0095 \\
(0.0146)\end{array}$ & \\
\hline Foreign bank branches & & & $\begin{array}{l}-0.0026 \\
(0.0050)\end{array}$ \\
\hline Gov. and gov.-influenced bank branches & & & $\begin{array}{l}-0.0007 \\
(0.0028)\end{array}$ \\
\hline Domestic private bank branches & & & $\begin{array}{l}-0.0034 \\
(0.0067)\end{array}$ \\
\hline Observations & 5314 & 5314 & 5314 \\
\hline Pseudo R-squared & 0.348 & 0.348 & 0.348 \\
\hline District Fixed Effects & YES & YES & YES \\
\hline Year Fixed Effects & YES & YES & YES \\
\hline
\end{tabular}


Number of Customer

(In Millions)

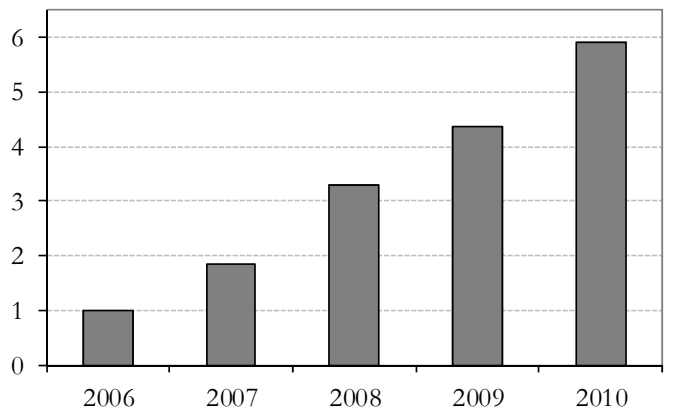

Gross Loan Portfolio

(In KShs Millions)

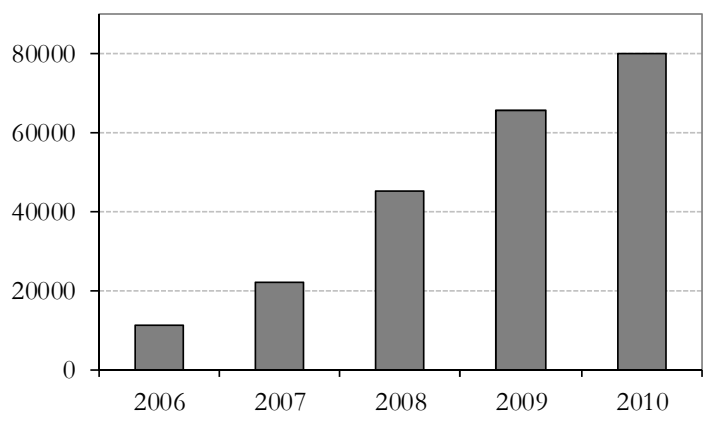

Profits Before Taxes

(In KShs Millions)

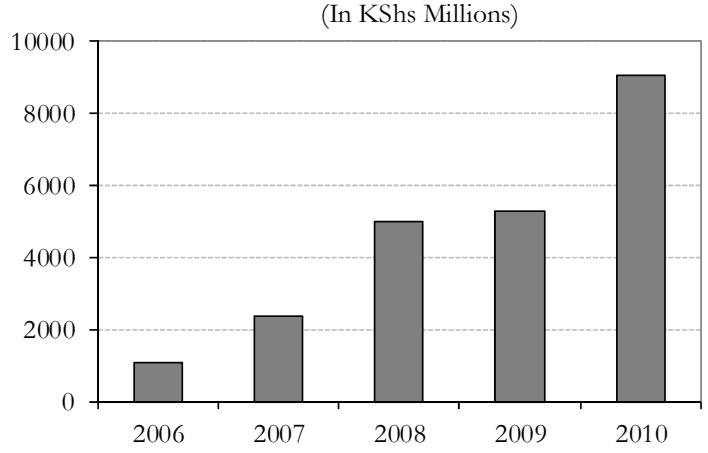

Customer Deposits
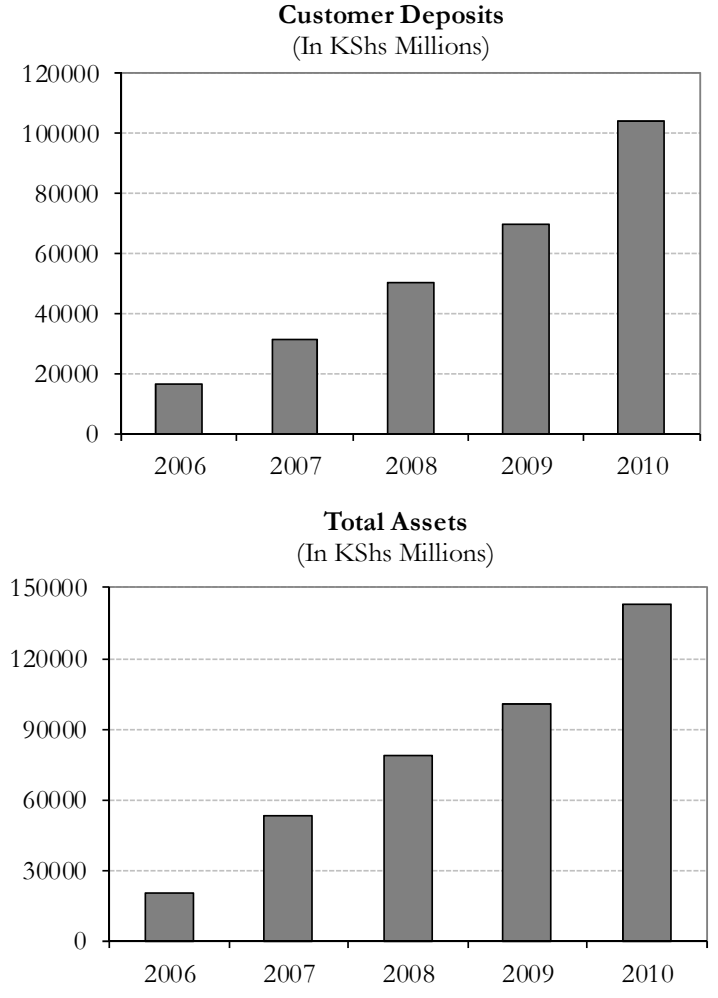

Shareholders' Funds

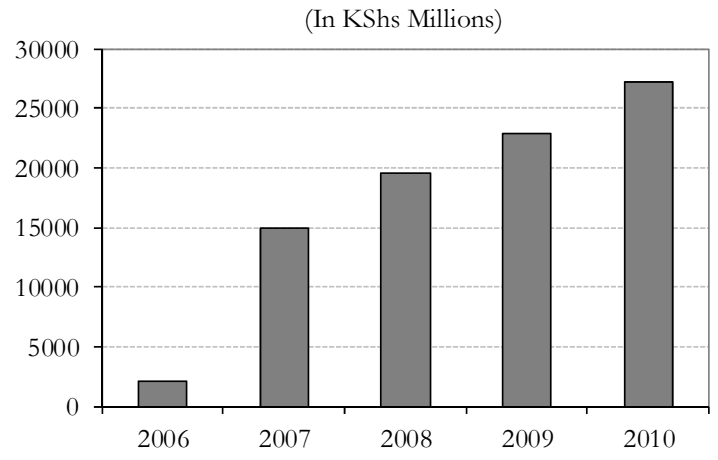

Figure 1. Equity Bank's performance indicators. This figure shows the evolution of the number of customers, deposits, gross loan portfolio, total assets, profits before taxes and shareholders' funds over the period 2006-2010. The source is Allen et al. (2012) based on data from the Equity Bank's Annual Reports and Financial Statements 2010. 

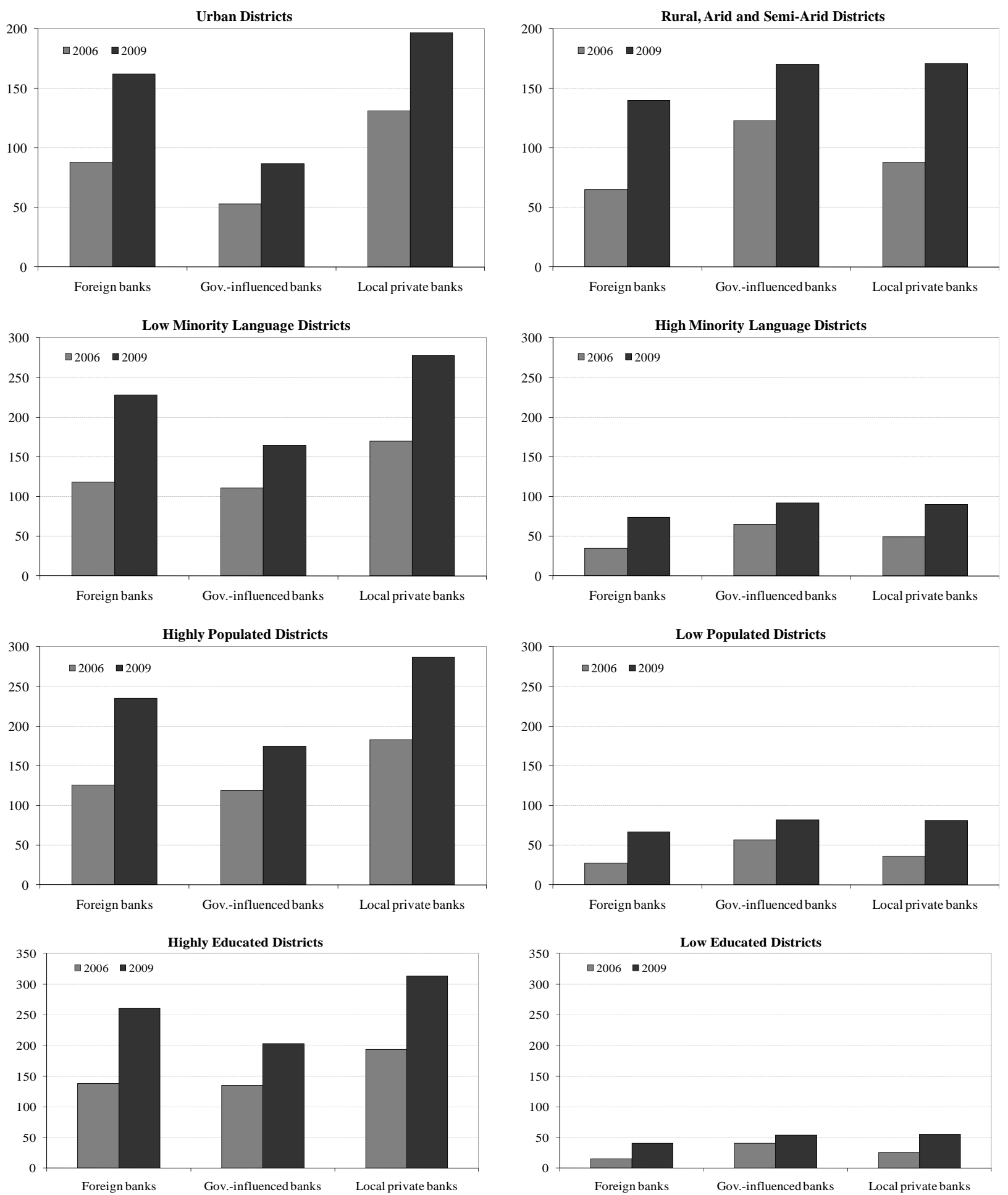

Figure 2. Bank Penetration in Kenya. This Figure shows the number of bank branches according to different ownership structures: Foreign banks, Government banks, and Domestic private banks. Urban districts include Nairobi and Mombasa districts. Low minority language districts are the ones where the share of the population speaking a minority language is smaller than the median. Highly populated districts are the ones where the density population is higher than the median. Highly educated districts are the ones where the share of the population with secondary or tertiary education is higher than the median. 